\title{
The Use of Limestones Built of Carbonate Phases with Increased Mg Content in Processes of Flue Gas Desulfurization
}

\author{
Katarzyna Jadwiga Stanienda-Pilecki
}

Citation: Stanienda-Pilecki, K.J. The Use of Limestones Built of Carbonate Phases with Increased Mg Content in Processes of Flue Gas Desulfurization. Minerals 2021, 11, 1044. https:// doi.org/10.3390/min11101044

Academic Editor: Dorota Kołodyńska

Received: 10 September 2021

Accepted: 22 September 2021

Published: 26 September 2021

Publisher's Note: MDPI stays neutral with regard to jurisdictional claims in published maps and institutional affiliations.

Copyright: (C) 2021 by the author. Licensee MDPI, Basel, Switzerland. This article is an open access article distributed under the terms and conditions of the Creative Commons Attribution (CC BY) license (https:// creativecommons.org/licenses/by/ $4.0 /)$.
Department of Applied Geology, Faculty of Mining, Safety Engineering and Industrial Automation, Silesian University of Technology, Akademicka 2 Street, 44-100 Gliwice, Poland; katarzyna.stanienda-pilecki@polsl.pl; Tel.: +48-32-237-27-34 or +48-32-237-10-26; Fax: +48-32-237-22-90

\begin{abstract}
The purpose of this article was to present the theory of the possibility of using limestone sorbents containing carbonate minerals with increased $\mathrm{Mg}$ content in processes of flue gas desulfurization in power stations. Data obtained as a result of the conducted research show that the analyzed Triassic (Muschelkalk) limestones of the south-west part of Poland are built of the following carbonate minerals: low magnesium calcite, high magnesium calcite, dolomite and huntite. These carbonate minerals are characterized by various magnesium contents. The increased content of magnesium in the sorbent has a positive effect on the technological process of flue gas desulfurization using the dry method, especially in the case of desulfurization with the application of Fluidized Bed Reactors. The positive influence of magnesium's presence in sorbent in the desulfurization process is connected with the decarbonization of carbonate phases with magnesium at temperatures similar to the dolomite decarbonization temperatures, which are, thus, lower than typical for low magnesium calcite. The process would be easier because the structure of a solid solution containing magnesium ions, with a smaller ion radius to calcium ions, is unstable and the decomposition of these phases runs easier and faster. Therefore, the desulfurization process starts earlier and is more effective.
\end{abstract}

Keywords: limestone; carbonate phases; sorbents; desulphurization processes

\section{Introduction}

Limestones are carbonate rocks that are applied in various industries. They are also used as a sorbent in processes of flue gas desulfurization in power stations. Limestones usually consist of calcite mineral $\left(\mathrm{CaCO}_{3}\right)$ known as low-Mg calcite. Some limestones also contain other carbonate minerals, such as high magnesium calcite, protodolomite, ordered dolomite and huntite [1-32]. These carbonate phases were determined during previous research on the Triassic (Muschelkalk) sediments located in the area of the Opole Silesia (south-west part of Poland). This area is a Polish zone of the Germanic Basin [18-28,33-35]. The rocks of this area are the subject of this article. The limestones that were analyzed are Lower Muschelkalk (Middle Triassic) sediments. The Muschelkalk profile contains Gogolin Beds (the bottom of the profile - initial sea transgressive stage), Górażdże Beds (advanced sea transgression stage), Dziewkowice (Terebratula) Beds (sea transgression peak stage) and Karchowice Beds (the top of the profile - sea regression stage). The names of formations are connected with the names of nearby situated cities [18-28,33-35]. The limestones of these units are built of carbonate minerals with various contents of $\mathrm{Ca}$ and $\mathrm{Mg}$, low magnesium calcite, high magnesium calcite, protodolomite [36], ordered dolomite and huntite.

The desulfurization of flue gases is a very significant process because now in Poland energy is still produced using brown coal and hard coal. Therefore, during coal combustion, the sulfur that is present in carbon is released and emitted in the form of sulfur oxides into the atmosphere. During the processes of flue gas desulfurization, the sulfur is bound to sulphate; therefore, the emission of sulfur oxides into the atmosphere is reduced. Limestone sorbent built of carbonate minerals with an increased $\mathrm{Mg}$ content could be used as a sorbent 
in the process of dry desulfurization, especially applying Fluidized Bed Reactor. The limestones sorbent that is usually used in flue gas desulfurization processes in power stations is built mainly of "pure", low magnesium calcite with contents of $\mathrm{MgO}<2 \%$ [37-43]. During this process, gypsum is formed [44-47].

The purpose of this article was to present the theory that the limestone containing carbonate phases with increased magnesium contents may be a better sorbent than the limestone built of "pure", low magnesium calcite, without the substitution of Mg ions. This problem was previously only mentioned in a few publications $[21,26,48,49]$ but detailed research, especially in the industry, has not been conducted. Therefore, the problem presented in this article can be treated as a novelty. It is worth analyzing the possibility of using limestones containing carbonate phases enriched in magnesium as a sorbent to determine the improvement of the flue gas desulphurization process efficiency in the case of using such a type of a sorbent. The improvement in the efficiency of the process is related to the faster decarbonization of magnesium-containing carbonates than of low$\mathrm{Mg}$ calcite. This is due to the difference in the ion radii of calcium and magnesium. The carbonization of carbonate phases rich in $\mathrm{Mg}$ decarbonization begins at a lower temperature than the decarbonization of low-Mg calcite; therefore, the desulfurization process starts earlier $[21,26,48,49]$. The sorbent with magnesium could be especially used when applying Fluidized Bed Reactor. It is a dry method of desulfurization. During the process, the coal combustion runs in the Fluidized Bed Reactor. The effectiveness of this method is $95 \%[21,26,40,41]$.

Due to the importance of this topic, research was undertaken. However, it was only possible to carry out laboratory tests. The next stage will be connected with conducting research in the industry, in power plants. However, this will be related to the application of limestone rich in magnesium in desulfurization installations used in power plants. The presented study's results indicate the possibility of using limestones containing carbonate phases rich in magnesium as a sorbent for flue gas desulphurization. Therefore, it will be worthwhile to conduct research on a semi-technological scale. The author aims to conduct research in a power plant, which would decide to apply a sorbent with magnesium in the desulfurization process.

\section{Materials and Methods}

\subsection{Materials}

The samples for laboratory tests that were conducted previously are characterized by the different contents of magnesium-rich carbonate phases. They were taken in selected places of the Opole Silesia area (Figure 1).

From all the samples taken, representative samples were selected for laboratory testing. Two samples were selected from those taken in Ligota Dolna Quarry-LD19 and LD20, and three from those taken in Gogolin Quarry-G1, G2, G6, and Wysoka QuarryW1, W5, W14). Four samples were selected from those taken in the area of Saint Anne Mountain-SA2, SA3, SA5, SA12, in Strzelce Opolskie Quarry—SO1, SO14, SO17, SO20, and in Szymiszów Quarry-S2, S7, S8, S9. In total, 20 limestone samples were examined. A total of 5 samples from Gogolin Unit (G1, G2, G6, LD9, LD11), 4 samples from Górażdże Unit (SA5, W1, W5, W14), 6 samples from Terebratula (Dziewkowice) Unit (SA12, SO1, S2, S7, S8, S9) and 5 samples from Karchowice Unit (SA2, SA3, SO14, SO17, SO20) were tested (Figure 1) [18-28,33].

\subsection{Methods}

All selected samples were tested using the following research methods: X-ray diffraction, Thermal Analysis, Fourier Transform Infrared Spectroscopy (FTIR, Laboratory of Faculty of Geography and Geology of the Jagiellonian University, Cracow, Poland), X-ray microanalysis (microprobe measurements, Center for Powder and Composite Materials of Institute of Non-ferrous Metals, Gliwice, Poland) and determination of sorption properties. 


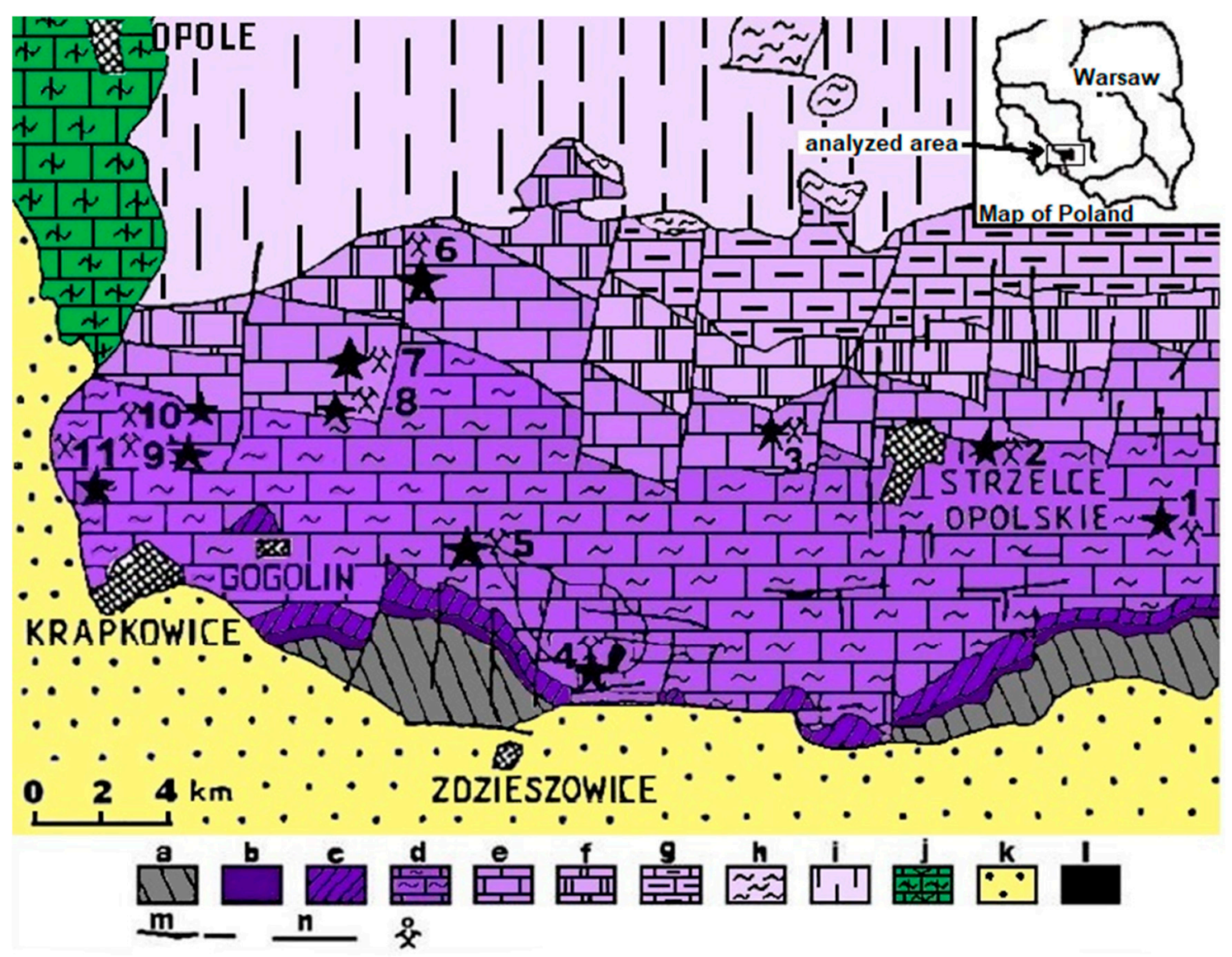

Figure 1. Geological simplified map of the central area of Opole Silesia, according to Niedźwiedzki [33], modified by Stanienda [21]. a-Lower Carboniferous (greywackes); b-Middle Buntsandstein (sandstones and mudstones); c-Upper Buntstandstein (Roethian) (limestones, dolomites and marls); d-Gogolin Beds (limestones and marls); e—Górażdże Beds (limestones), Terebratula Beds and Karchowice Beds (limestones); f-Jemielnice Beds (dolomites); g-Rybna Beds and Boruszowice Beds (limestones and dolomites); h-Keuper (claystones, mudstones and sandstones); i-Rhaetian (claystones); j-Upper Cretaceous (sandstones, marls and limestones); k-Neogene (sandstones, clays and gravels); l-Tertiary (basalts); m-faults; n-stratigraphic boundaries; o-important quarries: 1-11—quarries and outcrops: 1-Błotnica Strzelecka; 2-Dziewkowice; 3-Szymiszów; 4-Góra Św. Anny and Wysoka; 5-Ligota Dolna and Kamienna; 6-Tarnów Opolski; 7-Kamień Śląski; 8-Górażdże and Kamionek; 9-Malnia; 10-Chorula; 11-Rogów Opolski areas of sampling.

A total of 8 selected samples were examined using X-ray diffraction: G1, G2 (from Gogolin Unit), SA5, W1 (from Górażdże Unit), S2, S7 (from Dziewkowice/Terebratula Unit), SO14 and SO20 (from Karchowice Unit). The selection of samples for X-ray diffraction was made on the basis of the $\mathrm{Mg}$ quantity determined during previously conducted tests, especially results of chemical analysis and the amount of carbonate phases differentiated in Mg content [21-27]. The X-ray diffraction was performed at the Department of Applied Geology in Gliwice (Gliwice, Poland). The diffractometer HZG4 (produced in East Germany), applying a copper lamp with a nickel screen, was used. The analysis conditions were as follows: voltage, $35 \mathrm{kV}$; intensity, $18 \mathrm{~mA}$. The reflective light method was used. The Dronek Software (Dronek-3 Software by Wacław Musiał, Poland) was applied for the evaluation.

Thermal Analysis was used to examine a total of 8 samples selected from all formations: G1, G6 (from Gogolin Unit), SA5, W1 (from Górażdże Unit), S2, S8 (from Dziewkowice/Terebratula Unit), SA2 and SO14 (from Karchowice Unit). The selection of samples for the tests was made mainly on the basis of the $\mathrm{Mg}$ content determined during previously conducted chemical analysis and X-ray diffraction [21-27]. Thermal analysis was performed at the Department of Applied Geology in Gliwice. Thermal analysis was conducted with an application of Derivatograph made by Hungarian Company-F. 
Paulik-J. Paulik-L. Erdey (Hungary), using the following measurement parameters: time of measurement-100 min, maximal temperature-1000 ${ }^{\circ} \mathrm{C}$, DTA (Differential Thermal Analysis) sensitivity-1/10, DTG (Differential Thermal Gravimetric Analysis) sensitivity1/5, TG (Thermogravimetry)—200 mg. Weight of samples: $900 \mathrm{mg}$.

Fourier Transform Infrared Spectroscopy (FTIR) was used to test a total of 8 samples selected from all formations: G1, G6 (from Gogolin Unit), SA5, W1 (from Górażdże Unit), SO1, S2 (from Dziewkowice/Terebratula Unit), SO14 and SO20 (from Karchowice Unit). The selection of samples for the tests was made mainly on the basis of the $\mathrm{Mg}$ content determined during previously conducted chemical analysis, thermal analysis and X-ray diffraction [21-27]. The tests were conducted at the Institute of Geological Sciences of the Jagiellonian University (Cracow, Poland). The research was carried out using an FTS 135 BioRad Fourier Spectrometer. The Bio-Rad Sadtler Division 1981-1993 software (Bio-Rad Laboratories, Cracow, Poland) was applied to elaborate spectra.

X-ray microanalysis (microprobe measurements) was used to test a total of 5 samples selected from all formations: G1 (from Gogolin Unit), SA5 (from Górażdże Unit), S2 (from Dziewkowice/Terebratula Unit) and samples SO14 and SO20 (from Karchowice Unit). The selection of samples for the tests was made mainly on the basis of the $\mathrm{Mg}$ content determined during previously conducted research [21-27]. The tests were conducted at the Institute of Non-ferrous Metals in Gliwice (Gliwice, Poland). The tests were conducted applying the method of X-ray microanalysis EPMA. A JXA-8230 X-ray microanalyzer manufactured by JOEL was used. The investigations were performed on polished sections. They were sputtered with a carbon coat. The analysis with the application of WDS spectrometers was conducted. It was conducted in microareas of samples. The WDS method was used to carry out quantitative analyses in microareas. The measurements were conducted in selected points that are characterized by various chemical compositions. The content of the $\mathrm{Mg}$, Si, $\mathrm{Al}, \mathrm{Ca}, \mathrm{K}, \mathrm{Ba}, \mathrm{Sr}, \mathrm{Fe}, \mathrm{Mn}$, as well as the $\mathrm{O}$ and $\mathrm{C}$ were determined. Usually, the carbonates burn during exposure to X-rays. Moreover, the samples were sputtered with a carbon coat. Therefore, the values of $\mathrm{O}$ and $\mathrm{C}$ were calculated, and the results of measurements were normalized to a value of $100 \%$. It allowed the author to establish the real contents of $\mathrm{O}$ and $\mathrm{C}$ elements. The results of the measurements of the rest of chemical elements are original data. The total amount of carbon $(\mathrm{C})$ and part of the oxygen $(\mathrm{O})$ amount formed carbonates. Remaining amount of the $\mathrm{O}$ formed aluminosilicates and quartz [18-28].

The following 14 samples were selected for the study of sorption properties: G1, G6, LD9, LD11 (from Gogolin Unit), SA5, W1, W5 (from Górażdże Unit), SA12, SO1, S8 (from Dziewkowice/Terebratula Unit), SA2, SO14, SO17 and SO20 (from Karchowice Unit) [21]. The main criteria for selecting samples for testing included choosing at least 3 samples from each formation and the selection of samples was made on the basis of the $\mathrm{Mg}$ content determined during previously conducted research [21-27]. The tests were conducted at the Faculty of Mechanical Engineering of the Silesian University of Technology. Samples with grain size $<0.16 \mathrm{~mm}$ were introduced into the gas zone of the furnace in a platinum boat. The furnace was heated to the maximum temperature of $1400^{\circ} \mathrm{C}$. The electric furnace with a PR-40/1400S quartz tube inside was produced by the Industrial Institute of Electronics in Warsaw. The limestone samples were introduced into the quartz tube to the furnace heating zone in porcelain boats. The first stage of the research consisted in drying the samples at a temperature of $378 \mathrm{~K}$ for about 15 to $20 \mathrm{~min}$. During this process, nitrogen $\left(\mathrm{N}_{2}\right)$ was passed through the quartz tube in the amount of $\mathrm{V}_{\mathrm{n} 2}=0.21 \mathrm{l} / \mathrm{min}$. In the second stage of the analysis, the samples were calcined and $\mathrm{SO}_{2}$ was sorbed by the released $\mathrm{CaO}$. These processes were carried out at a temperature of $1223 \mathrm{~K}$ for a period of about $90 \mathrm{~min}$. In this step, the nitrogen flow was set with the flow meter at the level $0.51 \mathrm{l}_{\mathrm{n}} / \mathrm{min}$. After reaching a temperature of $1223 \mathrm{~K}$, sulfur dioxide $\left(\mathrm{SO}_{2}\right)$ was introduced into the nitrogen stream. 


\section{Results of Study}

\subsection{Carbonate Minerals in Limestones}

The data obtained during the previously made research [20-28] allowed the author to distinguish the following carbonate phases that are characterized by a variable content of Mg: low magnesium calcite, high magnesium calcite, protodolomite, ordered dolomite and huntite. The results of the X-ray diffraction and the Fourier Transform Infrared Spectroscopy (FTIR) allowed the author to identify the dolomite mineral without distinguishing whether it is a protodolomite or an ordered dolomite.

\subsubsection{The Results of the X-ray Diffraction}

The data obtained as a result of the X-ray diffraction allowed the author to identify four carbonate phases differentiated in terms of $\mathrm{Mg}$ content. These minerals were determined in almost all the tested samples. They are low magnesium calcite, high magnesium calcite, dolomite and, in a small amount, huntite occurs (Figures 2-5) [24].

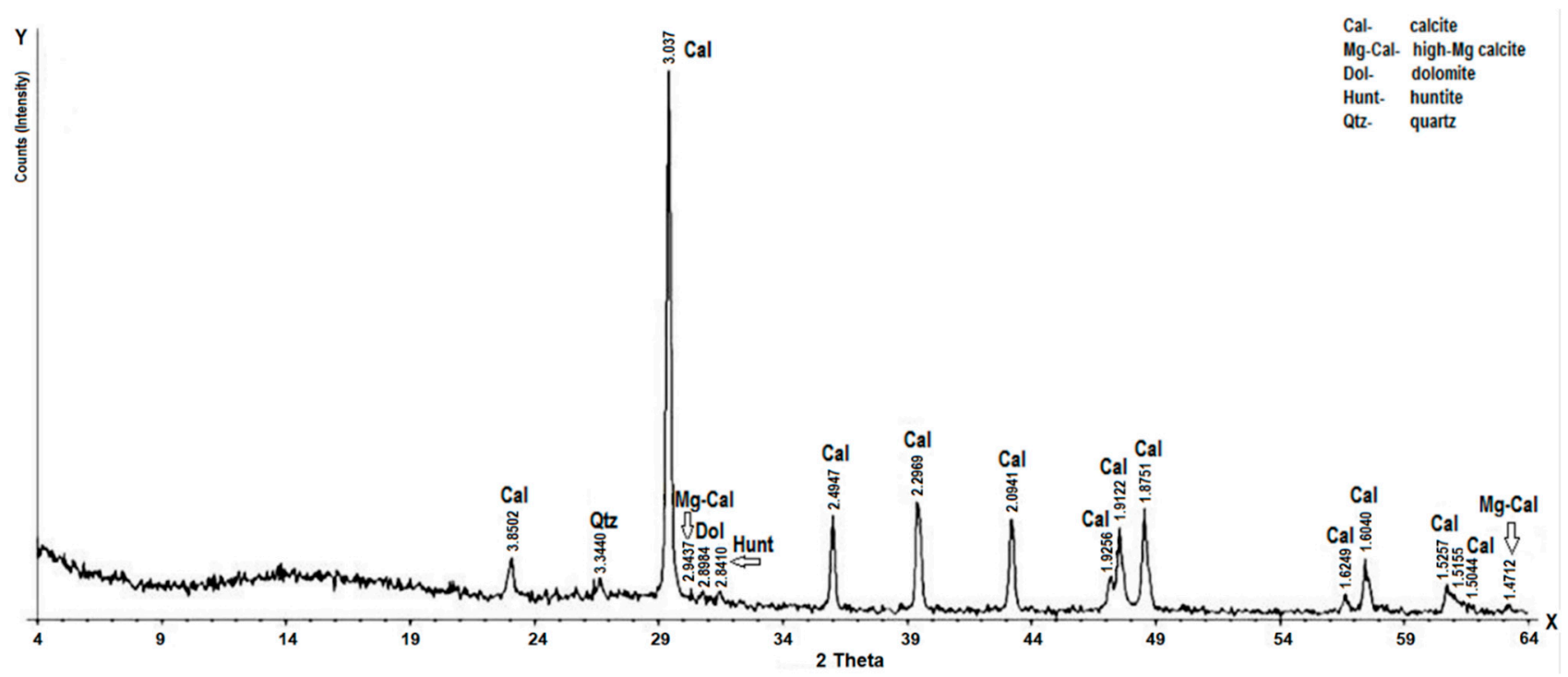

Figure 2. Diffractogram of sample G2, limestone of Gogolin Unit taken in the Gogolin Quarry [24].

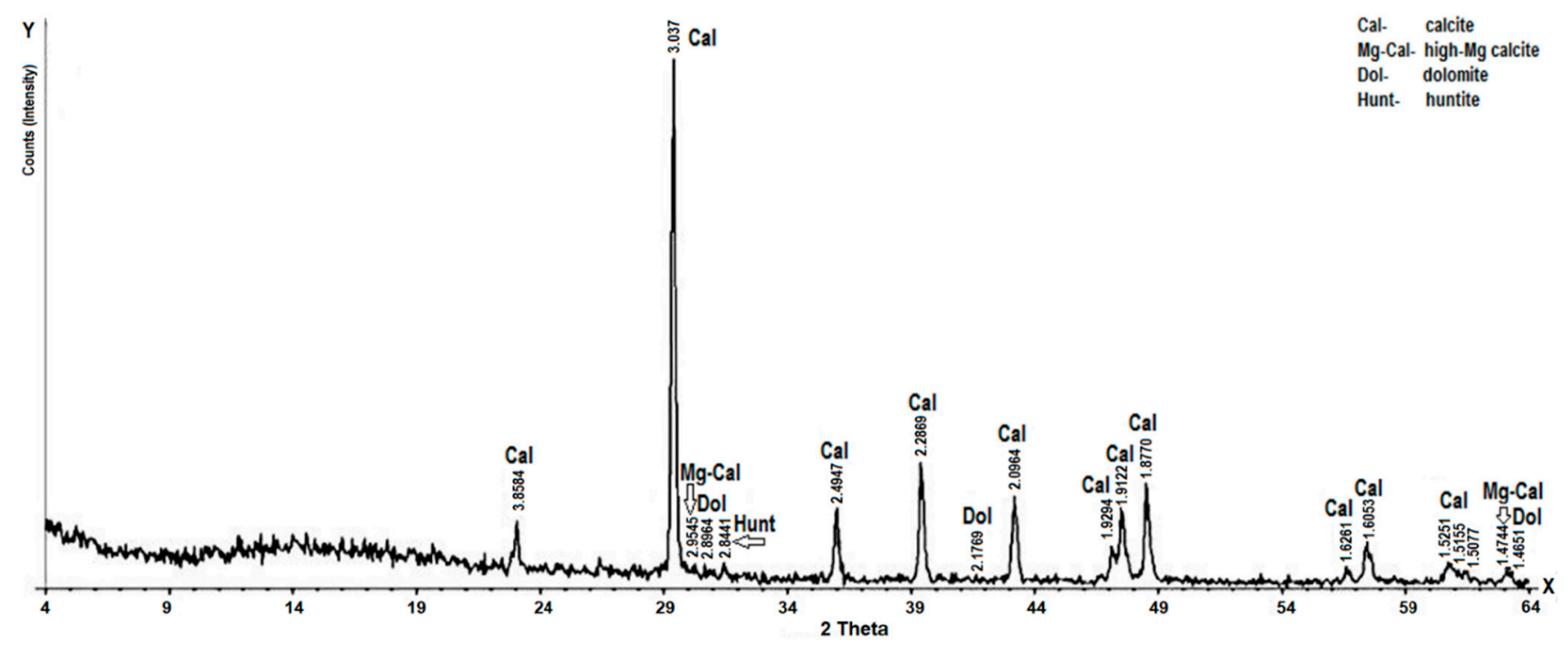

Figure 3. Diffractogram of sample W1, limestone of the Górażdże Unit taken in the Wysoka Quarry [24]. 


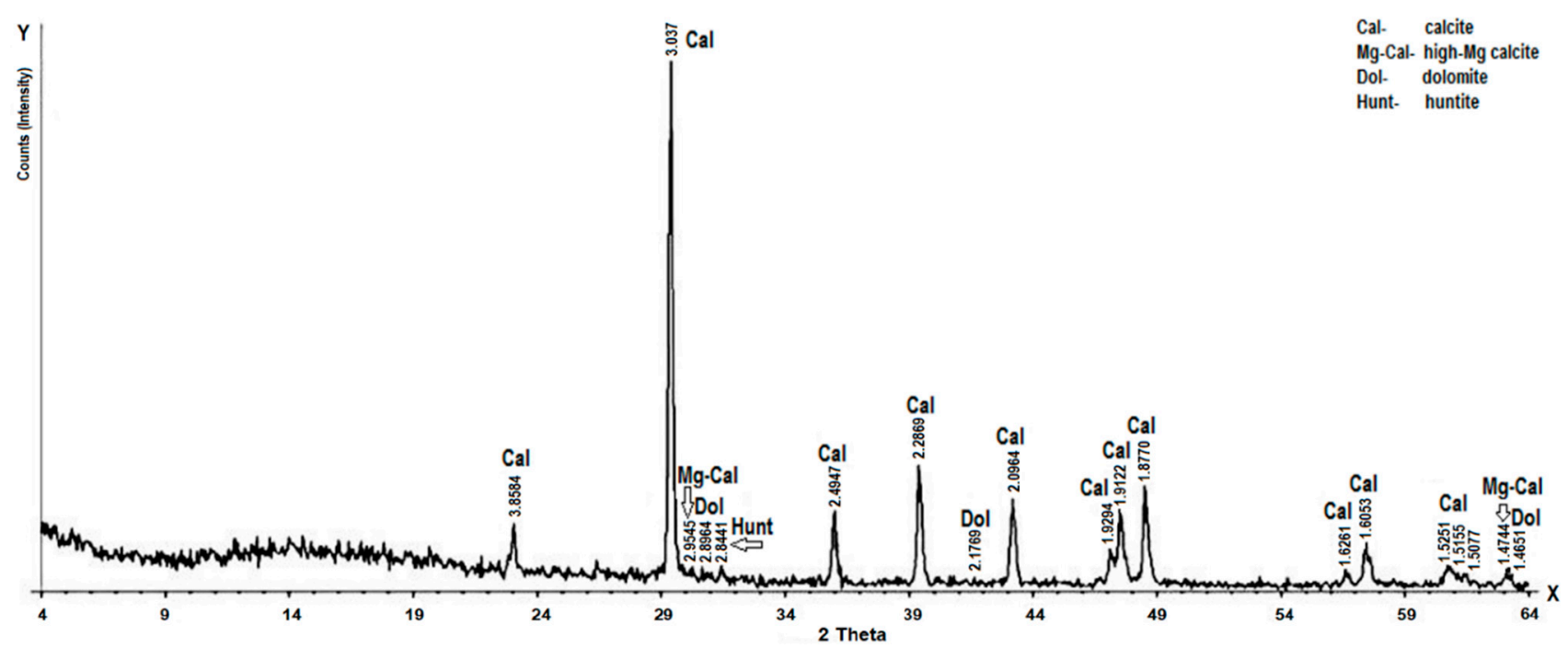

Figure 4. Diffractogram of sample S7, limestone of the Dziewkowice Unit taken in the Szymiszów Quarry [24].

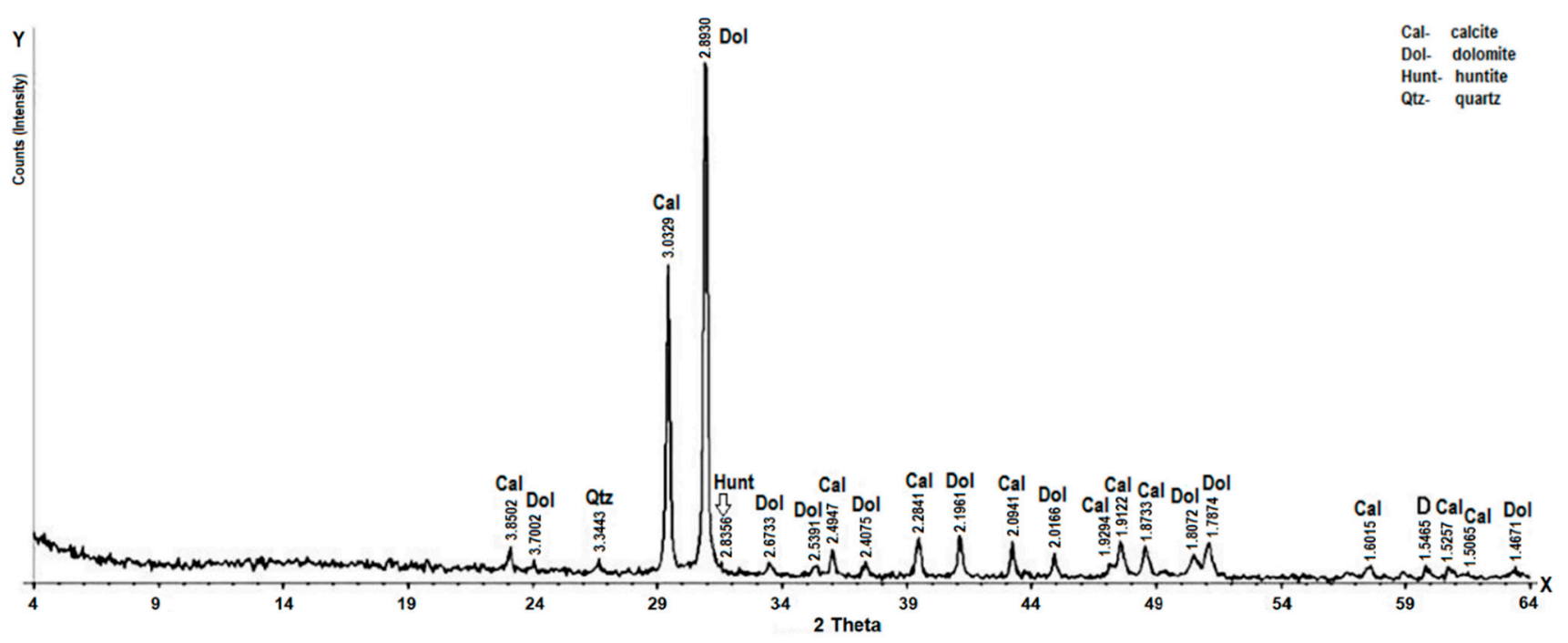

Figure 5. Diffractogram of sample SO14, limestone of the Karchowice Unit taken in the Strzelce Opolskie Quarry [24].

The results of X-ray diffraction presented on the attached diffractograms indicate the domination of low magnesium calcite in limestones. On the diffractograms of samples G2, W1 and S7, only two diffraction lines of high-Mg calcite occur. One of them is the diffraction line of the highest intensity. However, merely two diffraction lines were determined; therefore, it can only be stated that high magnesium calcite is probably present in the analyzed samples.

\subsubsection{The Results of the Thermal Analysis}

Based on the results of derivatographic analysis, mainly calcite was identified in the tested samples (endothermic effect $890-950{ }^{\circ} \mathrm{C}$ ); only one of the samples (SO14) showed the presence of dolomite (endothermic effect $790-810^{\circ} \mathrm{C}$ and $910-940{ }^{\circ} \mathrm{C}$ ) (Figure 6) [21]. Based on the obtained test results, the weight losses for individual samples were calculated. The increased content of $\mathrm{MgO}-6.98 \%$, determined during the chemical analysis of the SO14 sample, confirms the presence of dolomite in this limestone. A slight curve of the DTA curve in sample S8 (Figure 7) may also indicate the presence of the magnesium-containing phase in the rock. The reduced temperature of the endothermic effect of calcite-about $900{ }^{\circ} \mathrm{C}$ (close to the value of the second endothermic effect for dolomite) in sample SA2 (Figure 8) may indicate the presence of magnesium calcite in limestones. Lowering the 
temperature of the endothermic effect of calcite may be related to the substitution of magnesium ions in place of calcium ions, in the crystal of this mineral [21].

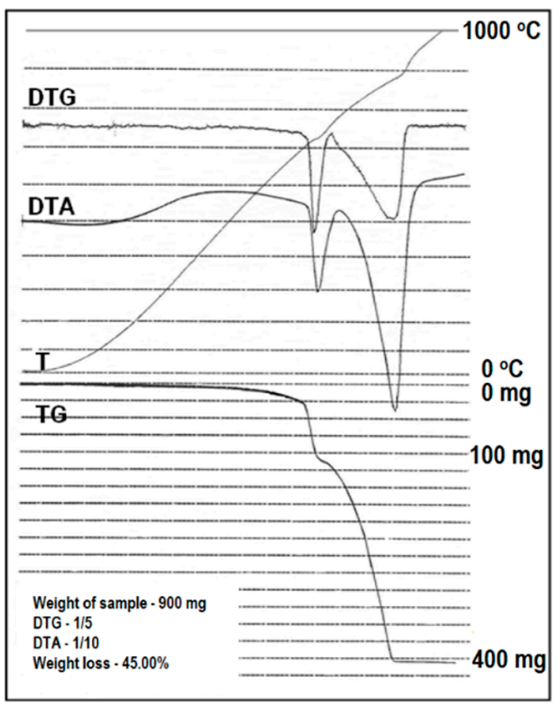

Figure 6. Derivatogram of sample SO14, limestone of the Karchowice Unit taken in the Strzelce Opolskie Quarry [21].

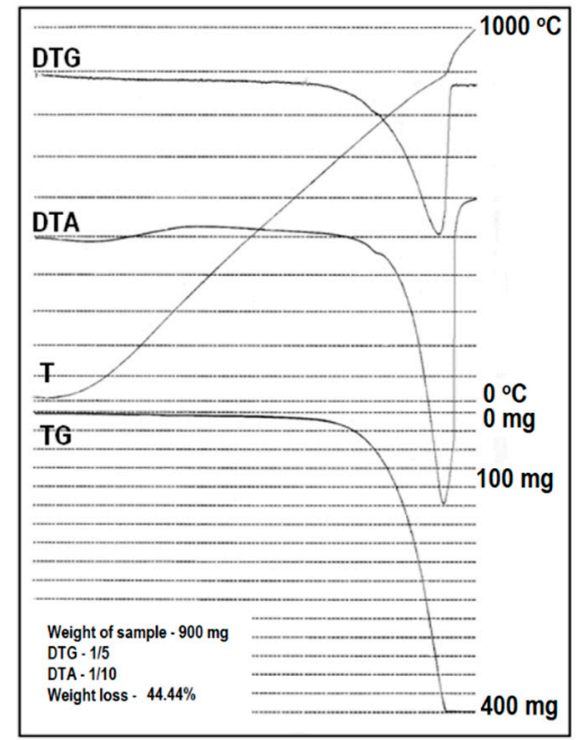

Figure 7. Derivatogram of sample S8, limestone of the Dziewkowice Unit taken in the Szymiszów Quarry [21].

\subsubsection{The Results of the Fourier Transform Infrared Spectroscopy (FTIR)}

Fourier Transform Infrared Spectroscopy (FTIR) allowed the author to identify low magnesium calcite, high magnesium calcite, dolomite and huntite [21,24]. These carbonate phases were determined on the basis of the typical infra-red absorption bands for these minerals $[21,24,46-48]$ (Figures 9-12). Low magnesium calcite was identified on the basis of the infra-red bands with the following values: $\mathrm{V}_{4}=712 \mathrm{~cm}^{-1}, \mathrm{~V}_{2}=847 \mathrm{~cm}^{-1}, \mathrm{~V}_{2}$-ranging from 872 to $874 \mathrm{~cm}^{-1}, \mathrm{~V}_{3}$-ranging from 1.415 to $1.422 \mathrm{~cm}^{-1}, \mathrm{~V}_{1}+\mathrm{V}_{4}$-ranging from 1.797 to $1.799 \mathrm{~cm}^{-1}, \mathrm{~V}_{1}+\mathrm{V}_{3}$-ranging from 2.512 to $2.513 \mathrm{~cm}^{-1}$ and the single bands of further infra-red [46-48]. High magnesium calcite was determined based on the following typical phase absorption bands for this carbonate: $\mathrm{V}_{3}=$ ranging from 1.426 to $1.435 \mathrm{~cm}^{-1}$, 
$\mathrm{V}_{1}+\mathrm{V}_{3}=2.519 \mathrm{~cm}^{-1}$ and $2.626 \mathrm{~cm}^{-1}$ and the absorption bands of further infra-red that have the following values: 1.087 and $2.356 \mathrm{~cm}^{-1}[6,21,24,46,48,49]$.

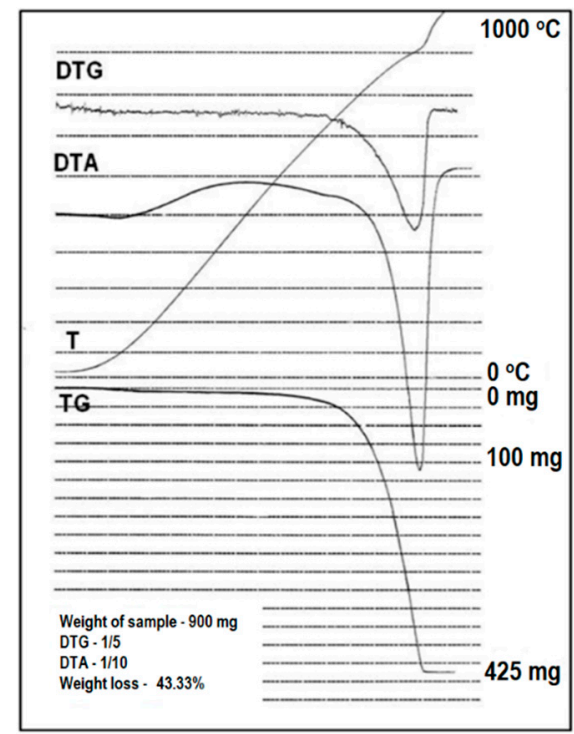

Figure 8. Derivatogram of sample SA2, limestone of the Karchowice Unit taken in the area of Saint Anne Mountain [21].

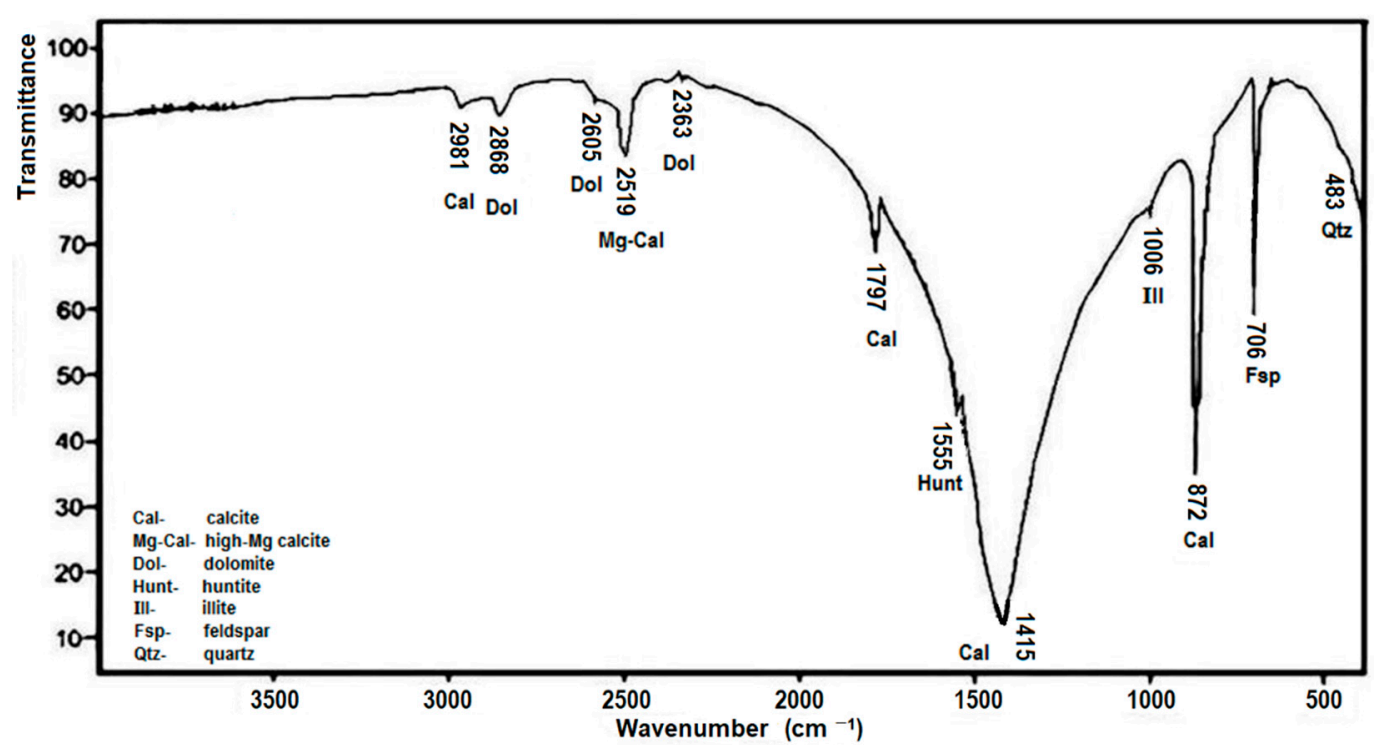

Figure 9. Infra-red absorption spectrum of sample G6, limestone of the Gogolin Unit taken in the Gogolin Quarry [21,22,24].

The absorption spectrum of sample G6 contains only one absorption band of high magnesium calcite. Therefore, it can only be stated that high magnesium calcite is probably present in this sample. Dolomite was identified mainly on the basis of the typical absorption bands of further infra-red measurements for dolomite [21,22,24,46-48] with the following values: $1.702 \mathrm{~cm}^{-1}, 2.360$ to $2.368 \mathrm{~cm}^{-1}, 2.605 \mathrm{~cm}^{-1}$ and $2.868 \mathrm{~cm}^{-1}$. Huntite was determined mainly on the basis of the single infra-red bands, the values for which are as follows: for sample G1-469 $\mathrm{cm}^{-1}$ and $800 \mathrm{~cm}^{-1}$, for samples G6 (Figure 9) and S2-1555 $\mathrm{cm}^{-1}$ and for sample SO1-1562 $\mathrm{cm}^{-1}$ (Figure 11) $[21,24,48]$. 


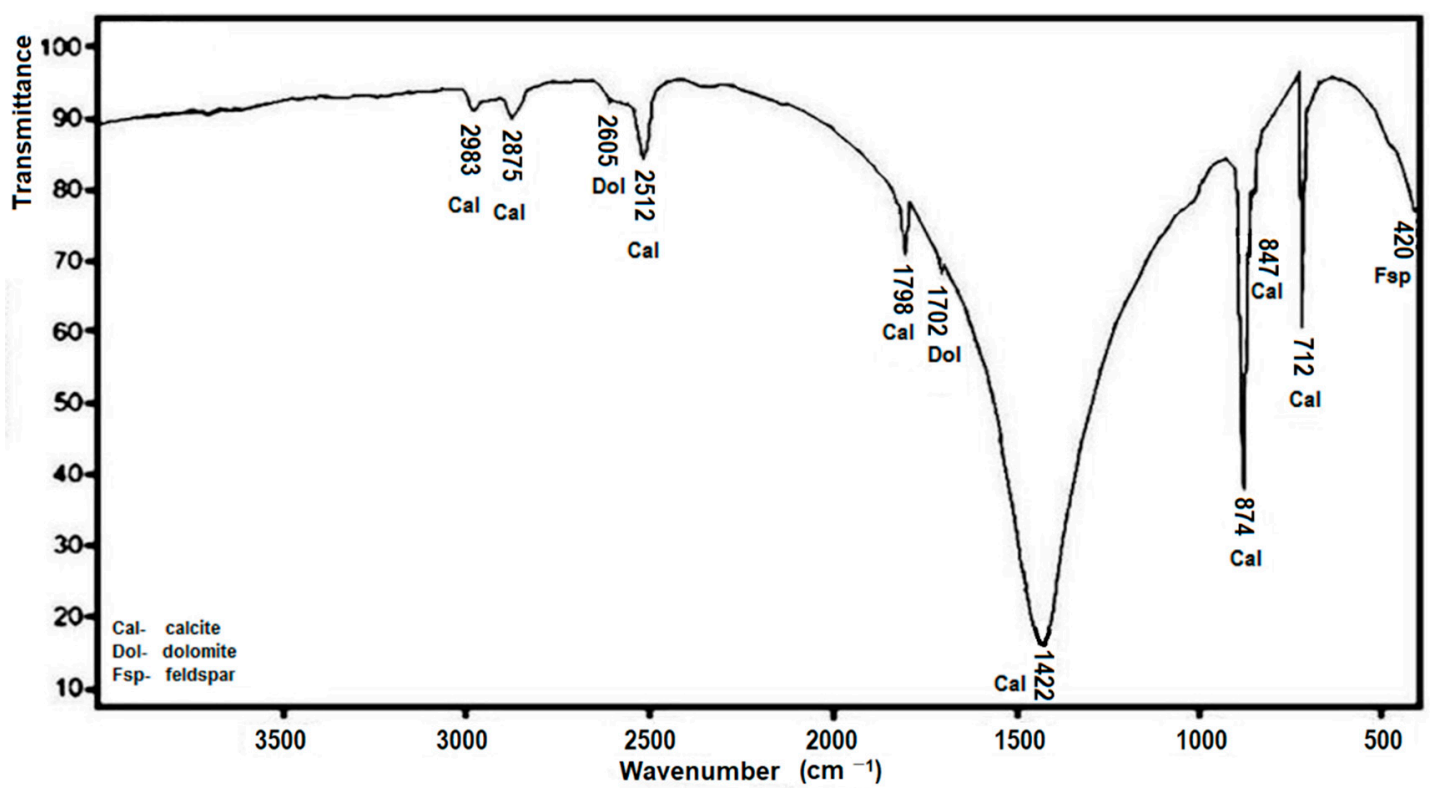

Figure 10. Infra-red absorption spectrum of sample W1, limestone of the Górażdże Unit taken in the Wysoka Quarry [21,22,24].

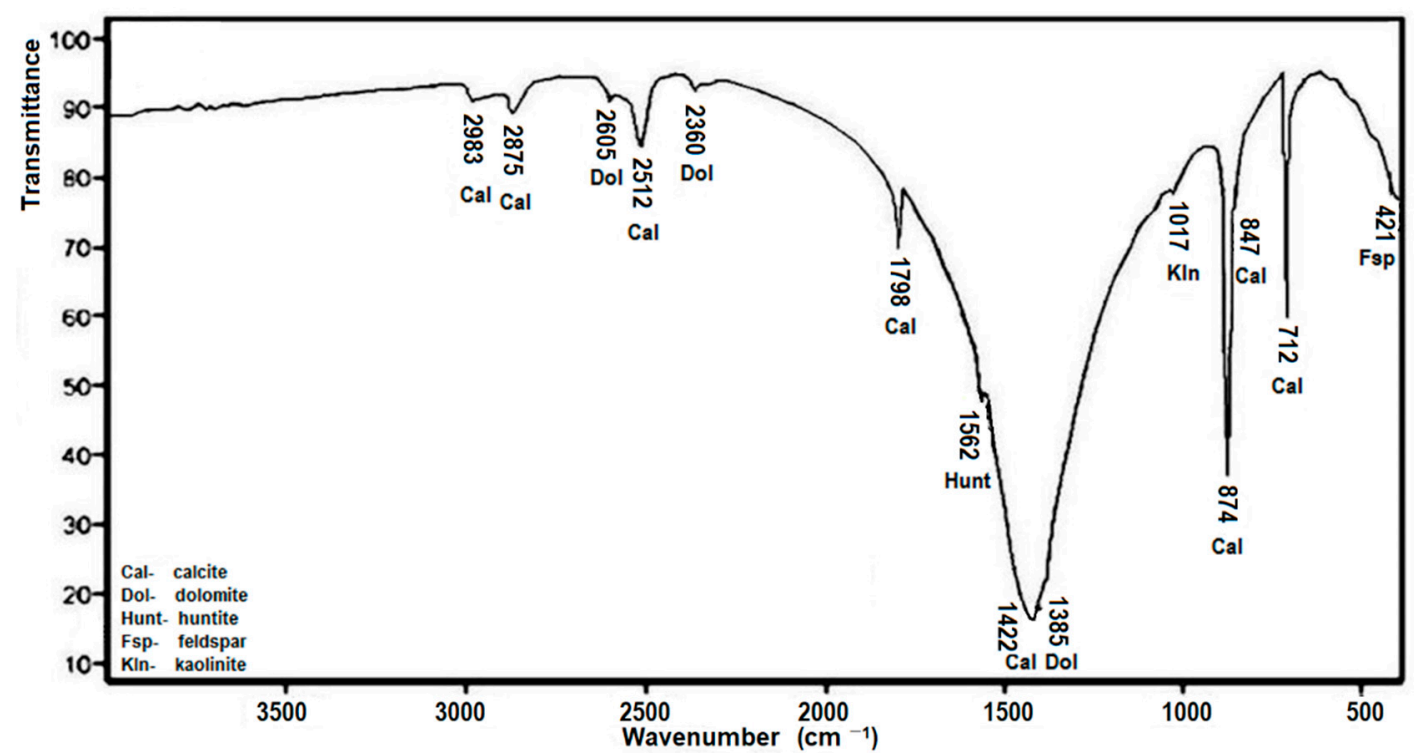

Figure 11. Infra-red absorption spectrum of sample SO1, limestone of the Dziewkowice Unit taken in the Strzelce Opolskie Quarry [21,22,24].

\subsubsection{The Results of X-ray Microanalysis (Microprobe Measurements)}

The X-ray microanalysis (microprobe measurements) was executed in a carbonate groundmass of samples, in points. BSE (Back-scattered Electron) images of the selected, representative for each examined sample microareas were taken. At the points of occurrence of the carbonate phases, the quantitative chemical composition was determined. This method allowed the author to determine the following carbonate phases: low magnesium calcite, high magnesium calcite, ordered dolomite and huntite [21,22,24]. The ordered dolomite is characterized by the value of $\mathrm{Mg}$ content close to the stoichiometric value for dolomite $(\mathrm{Mg}=13.18 \%, \mathrm{MgO}=21.86 \%)$. Examples of the results of two samples-S2 (limestone of the Dziewkowice Unit taken in the Szymiszów Quarry) and SO14 (limestone of the Karchowice Unit taken in the Strzelce Opolskie Quarry)-are presented below (Figures 13 and 14, Tables 1 and 2). 


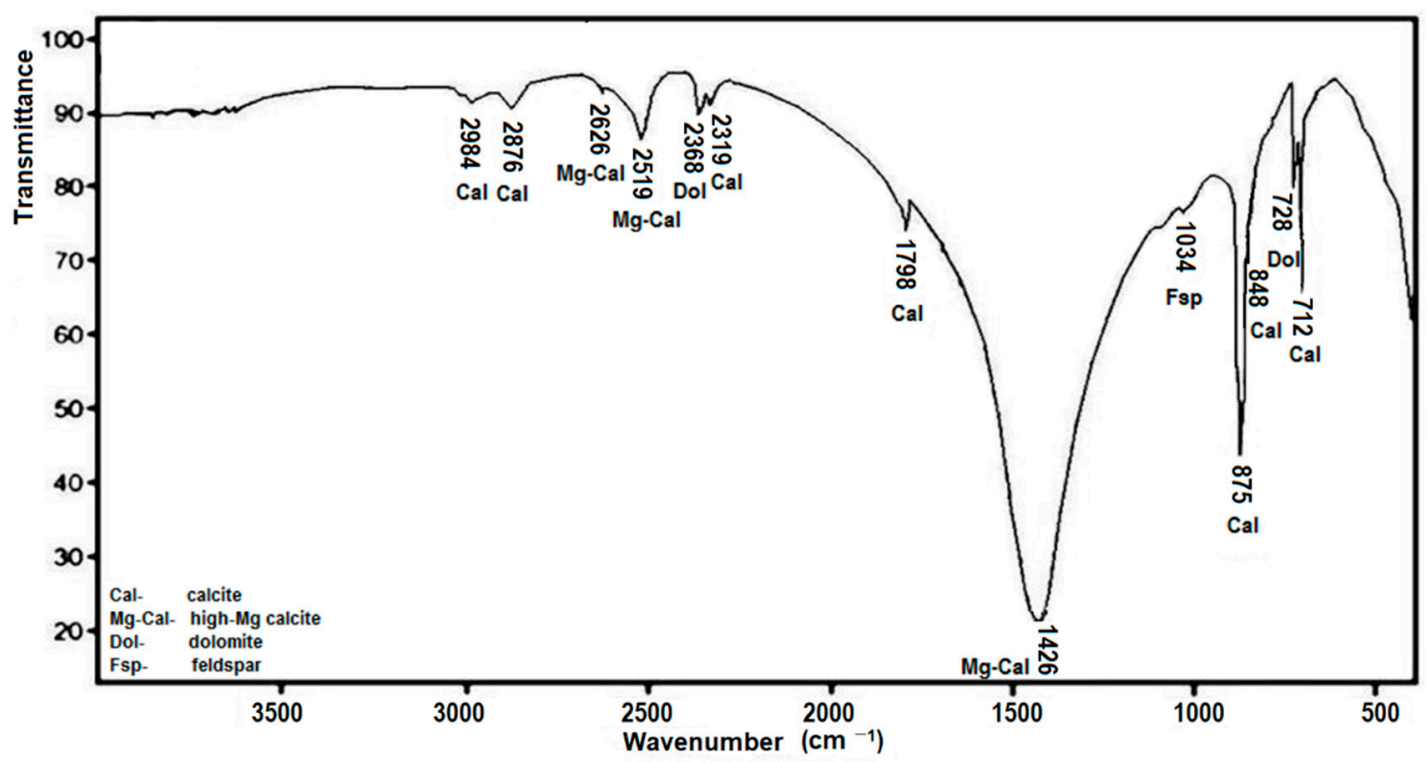

Figure 12. Infra-red absorption spectrum of sample SO14, limestone of the Karchowice Unit taken in the Strzelce Opolskie Quarry [21,22,24].

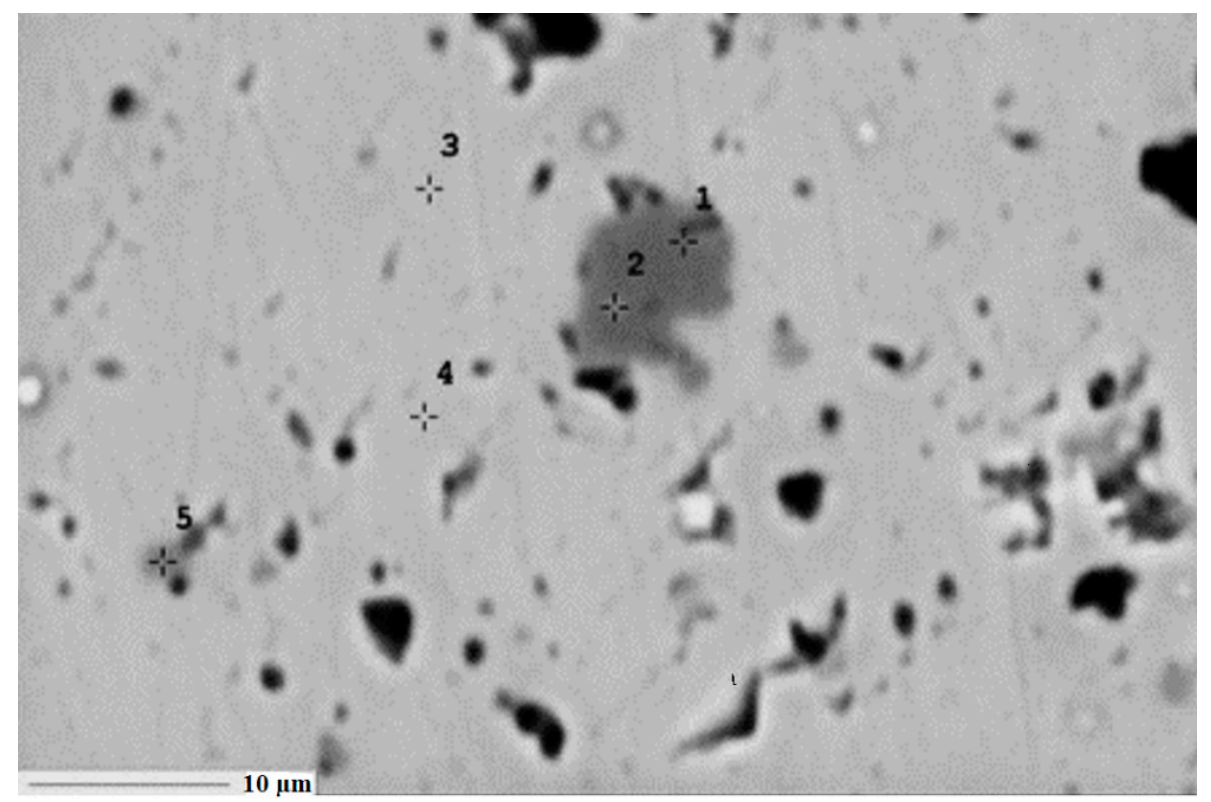

Figure 13. BSE image of sample S2, limestone of the Dziewkowice Unit taken in the Szymiszów Quarry. Magn. 2000×,1-5-points of chemical analysis [21,24].

The research results show that investigated limestones contain carbonate phases varying in magnesium content. It is very important due to the rapidity and effectiveness of the flue gas desulphurization process. It is related to the faster disintegration of the carbonate phase cells that contain magnesium compared to the cells of "pure calcite". The substitution of magnesium ions in carbonate minerals causes a reduction in ionic bond strength. Therefore, the decarbonization of carbonate minerals with increased magnesium contents runs at lower temperatures. Thus, the decarbonation of carbonate phases rich in magnesium - high-Mg calcite, dolomite and huntite-will occur faster and at temperatures that are lower than the decomposition temperatures of low-magnesium calcite. 


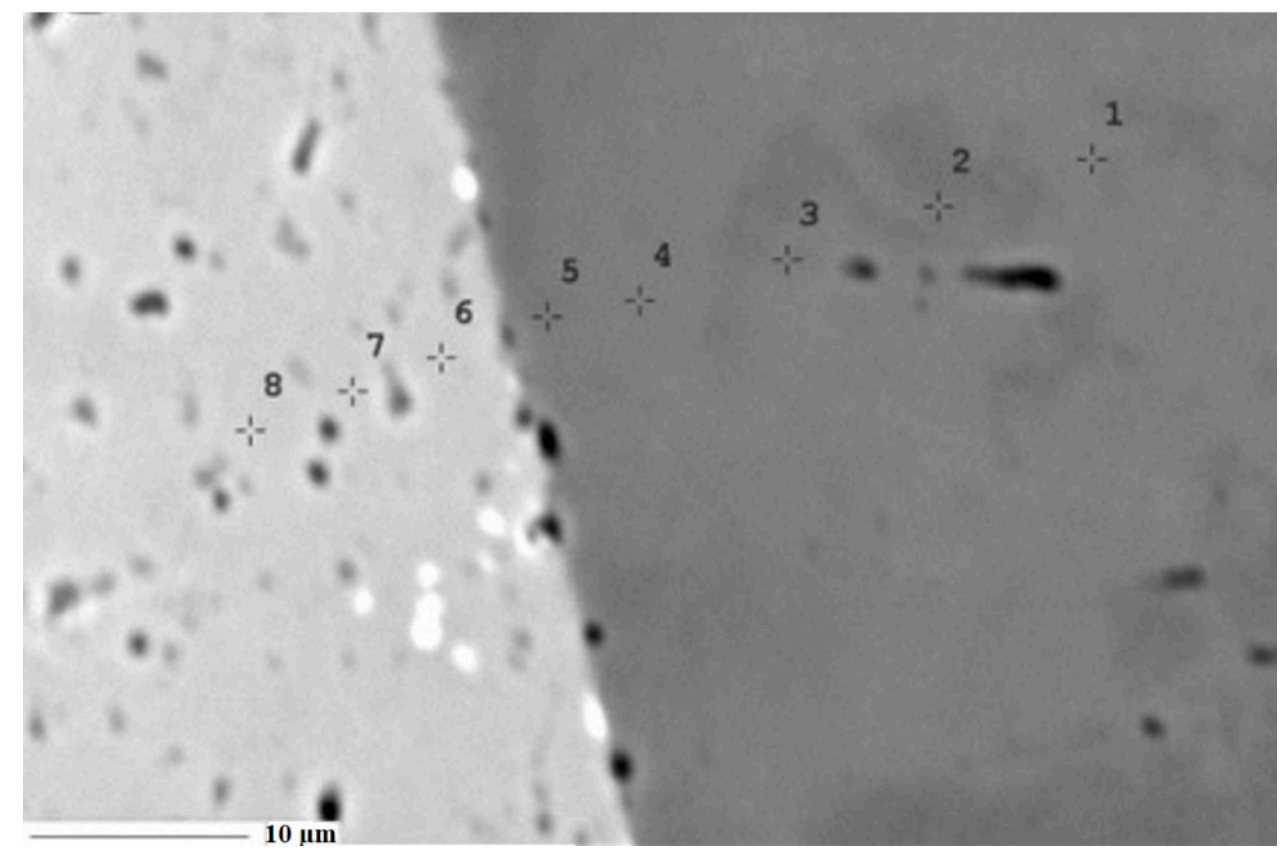

Figure 14. BSE image of sample SO14, limestone of the Karchowice Unit taken in the Strzelce Opolskie Quarry. Magn. 2000×,1-8-points of chemical analysis [22,24].

Table 1. Results of the microprobe measurements of sample S2 [21,24].

\begin{tabular}{|c|c|c|c|c|c|c|c|c|c|c|c|c|c|}
\hline \multirow{2}{*}{$\begin{array}{l}\text { Point } \\
\text { Number }\end{array}$} & \multirow[b]{2}{*}{ Mineral } & \multicolumn{11}{|c|}{ Type of Chemical Element (\%mass) (Figure 10) } & \multirow[b]{2}{*}{ Total } \\
\hline & & $\begin{array}{c}\mathrm{O} \\
\text { Normalized }\end{array}$ & $\begin{array}{c}C \\
\text { Normalized }\end{array}$ & $\mathrm{Mg}$ & Si & Al & $\mathrm{Ca}$ & $\mathbf{K}$ & Ba & Sr & $\mathbf{F e}$ & Mn & \\
\hline 1 & $\begin{array}{l}\text { Ordered Dolomite } \\
{\left[\mathrm{Ca}_{0.53}, \mathrm{Mg}_{0.47} \mathrm{CO}_{3}\right]}\end{array}$ & 53.80 & 8.80 & 13.20 & 0.00 & 0.00 & 24.20 & 0.00 & 0.00 & 0.00 & 0.00 & 0.00 & 100.00 \\
\hline 2 & $\begin{array}{l}\text { High-Mg Calcite } \\
\left(\mathrm{Ca}_{0.60}, \mathrm{Mg}_{0.40}\right) \mathrm{CO}_{3}\end{array}$ & 54.80 & 8.00 & 10.70 & 0.00 & 0.00 & 26.30 & 0.00 & 0.00 & 0.00 & 0.20 & 0.00 & 100.00 \\
\hline 3 & $\begin{array}{l}\text { Low-Mg Calcite } \\
\left(\mathrm{Ca}_{0.99}, \mathrm{Mg}_{0.01}\right) \mathrm{CO}_{3}\end{array}$ & 50.60 & 8.00 & 0.30 & 0.00 & 0.00 & 41.00 & 0.00 & 0.00 & 0.10 & 0.00 & 0.00 & 100.00 \\
\hline 4 & $\begin{array}{l}\text { Low-Mg Calcite } \\
\left(\mathrm{Ca}_{0.99}, \mathrm{Mg}_{0.01}\right) \mathrm{CO}_{3}\end{array}$ & 46.70 & 11.60 & 0.20 & 0.00 & 0.00 & 41.50 & 0.00 & 0.00 & 0.00 & 0.00 & 0.00 & 100.00 \\
\hline 5 & $\begin{array}{l}\text { High-Mg Calcite } \\
\left(\mathrm{Ca}_{0.77}, \mathrm{Mg}_{0.23}\right) \mathrm{CO}_{3}\end{array}$ & 45.90 & 8.60 & 7.10 & 0.00 & 0.00 & 38.40 & 0.00 & 0.00 & 0.00 & 0.00 & 0.00 & 100.00 \\
\hline
\end{tabular}

3.2. Limestone Built of Carbonate Minerals with Increased Mg Content as a Sorbent in Flue Gas Desulfurization

\subsubsection{Results of Sorption Tests}

Fourteen samples from all four limestone formations were selected for sorption studies. The samples were analyzed for $\mathrm{SO}_{2}$ absorption properties, depending on the $\mathrm{MgO}$ content. Sample drying time-15 to $20 \mathrm{~min}$, calcination and sorption time-approx. $90 \mathrm{~min}$. The test results are presented in Table 3 and Figures 15-18 [21]. 
Table 2. Results of the microprobe measurements of a sample SO14 [22,24].

\begin{tabular}{|c|c|c|c|c|c|c|c|c|c|c|c|c|c|}
\hline \multirow{2}{*}{$\begin{array}{l}\text { Point } \\
\text { Number }\end{array}$} & \multirow[b]{2}{*}{ Mineral } & \multicolumn{11}{|c|}{ Type of Chemical Element (\%mass) (Figure 11) } & \multirow[b]{2}{*}{ Total } \\
\hline & & $\begin{array}{c}\text { O } \\
\text { Normalized }\end{array}$ & $\begin{array}{c}\text { C } \\
\text { Normalized }\end{array}$ & $\mathrm{Mg}$ & Si & Al & $\mathrm{Ca}$ & $\mathbf{K}$ & Ba & Sr & $\mathrm{Fe}$ & Mn & \\
\hline 1 & $\begin{array}{c}\text { Huntite } \\
{\left[\mathrm{Ca}_{0.48}, \mathrm{Mg}_{0.52} \mathrm{CO}_{3}\right]}\end{array}$ & 48.36 & 11.543 & 14.04 & 0.00 & 0.029 & 25.19 & 0.00 & 0.00 & 0.024 & 0.814 & 0.00 & 100.00 \\
\hline 2 & $\begin{array}{c}\text { Huntite } \\
{\left[\mathrm{Ca}_{0.47}, \mathrm{Mg}_{0.53} \mathrm{CO}_{3}\right]}\end{array}$ & 47.32 & 12.902 & 14.01 & 0.00 & 0.017 & 24.78 & 0.00 & 0.00 & 0.00 & 0.971 & 0.00 & 100.00 \\
\hline 3 & $\begin{array}{l}\text { Ordered Dolomite } \\
{\left[\mathrm{Ca}_{0.53}, \mathrm{Mg}_{0.47} \mathrm{CO}_{3}\right]}\end{array}$ & 49.02 & 11.526 & 13.42 & 0.00 & 0.017 & 24.87 & 0.010 & 0.00 & 0.00 & 1.093 & 0.044 & 100.00 \\
\hline 4 & $\begin{array}{c}\text { Huntite } \\
{\left[\mathrm{Ca}_{0.46}, \mathrm{Mg}_{0.54} \mathrm{CO}_{3}\right]}\end{array}$ & 46.59 & 12.187 & 14.72 & 0.00 & 0.033 & 24.99 & 0.001 & 0.080 & 0.00 & 1.399 & 0.000 & 100.00 \\
\hline 5 & $\begin{array}{c}\text { Huntite } \\
{\left[\mathrm{Ca}_{0.48}, \mathrm{Mg}_{0.52} \mathrm{CO}_{3}\right]}\end{array}$ & 45.60 & 12.36 & 15.92 & 0.005 & 0.025 & 24.78 & 0.00 & 0.00 & 0.017 & 1.266 & 0.027 & 100.00 \\
\hline 6 & $\begin{array}{l}\text { Low-Mg Calcite } \\
\left(\mathrm{Ca}_{0.99}, \mathrm{Mg}_{0.01}\right) \mathrm{CO}_{3}\end{array}$ & 42.82 & 14.967 & 0.186 & 0.00 & 0.017 & 41.88 & 0.00 & 0.00 & 0.00 & 0.109 & 0.021 & 100.00 \\
\hline 7 & $\begin{array}{l}\text { Low-Mg Calcite } \\
\left(\mathrm{Ca}_{0.99}, \mathrm{Mg}_{0.01}\right) \mathrm{CO}_{3}\end{array}$ & 44.71 & 12.495 & 0.159 & 0.00 & 0.00 & 42.53 & 0.00 & 0.00 & 0.00 & 0.106 & 0.00 & 100.00 \\
\hline 8 & $\begin{array}{l}\text { Low-Mg Calcite } \\
\qquad \mathrm{CaCO}_{3}\end{array}$ & 43.18 & 12.445 & 0.104 & 0.00 & 0.00 & 44.02 & 0.00 & 0.008 & 0.00 & 0.238 & 0.005 & 100.00 \\
\hline
\end{tabular}

Table 3. Results of sorption tests [21].

\begin{tabular}{|c|c|c|c|c|c|c|c|c|c|}
\hline No & Unit & $\begin{array}{l}\text { Sample } \\
\text { Number }\end{array}$ & $\underset{(\%)}{\mathrm{MgO}}$ & $\begin{array}{c}\text { Sample } \\
\text { Weight (g) }\end{array}$ & $\begin{array}{c}\text { Drying } \\
\text { Temperature } \\
\text { (K) }\end{array}$ & $\begin{array}{c}\text { Calcination } \\
\text { Temperature } \\
\text { (K) }\end{array}$ & $\begin{array}{l}\mathrm{SO}_{2} \text { Stream Flowing } \\
\text { through the } \\
\text { Installation }(\mathrm{mg} / \mathrm{min})\end{array}$ & $\begin{array}{l}\text { Quantity of S in } \\
\text { a Post-Absorbent } \\
\text { Product (\%) }\end{array}$ & $\begin{array}{l}\text { The Amount of } \\
\mathrm{SO}_{2} \text { Absorbed } \\
\text { during the Test }\end{array}$ \\
\hline 1 & & G1 & 0.83 & 3.1835 & 378 & 1223 & 7.31 & 0.43 & 0.86 \\
\hline 2 & Gogolin & G6 & 0.22 & 5.0632 & 378 & 1223 & 7.81 & 0.27 & 0.54 \\
\hline 3 & Unit & LD9 & 0.90 & 2.5265 & 378 & 1223 & 7.39 & 0.38 & 0.76 \\
\hline 4 & & LD11 & 0.80 & 1.9895 & 378 & 1223 & 4.60 & 0.31 & 0.62 \\
\hline 5 & & W1 & 0.99 & 2.5647 & 378 & 1223 & 7.86 & 0.25 & 0.50 \\
\hline 6 & Górażdże & W5 & 0.99 & 2.5379 & 378 & 1223 & 8.23 & 0.18 & 0.36 \\
\hline 7 & Unit & SA5 & 0.36 & 2.0750 & 378 & 1223 & 8.46 & 0.26 & 0.52 \\
\hline 8 & & SA12 & 0.80 & 2.1472 & 378 & 1223 & 8.77 & 0.24 & 0.48 \\
\hline 9 & Dziewkowice & S8 & 0.85 & 4.5833 & 378 & 1223 & 6.63 & 0.24 & 0.48 \\
\hline 10 & Unit & SO1 & $0, .76$ & 2.3942 & 378 & 1223 & 8.16 & 0.34 & 0.68 \\
\hline 11 & & SA2 & 5.67 & 1.7481 & 378 & 1223 & 9.38 & 0.28 & 0.56 \\
\hline 12 & Karchowice & SO14 & 6.98 & 2.3891 & 378 & 1223 & 5.39 & 0.30 & 0.60 \\
\hline 13 & Unit & SO17 & 8.72 & 3.3464 & 378 & 1223 & 5.24 & 0.31 & 0.62 \\
\hline 14 & & SO20 & 0.89 & 4.1621 & 378 & 1223 & 8.23 & 0.37 & 0.74 \\
\hline
\end{tabular}

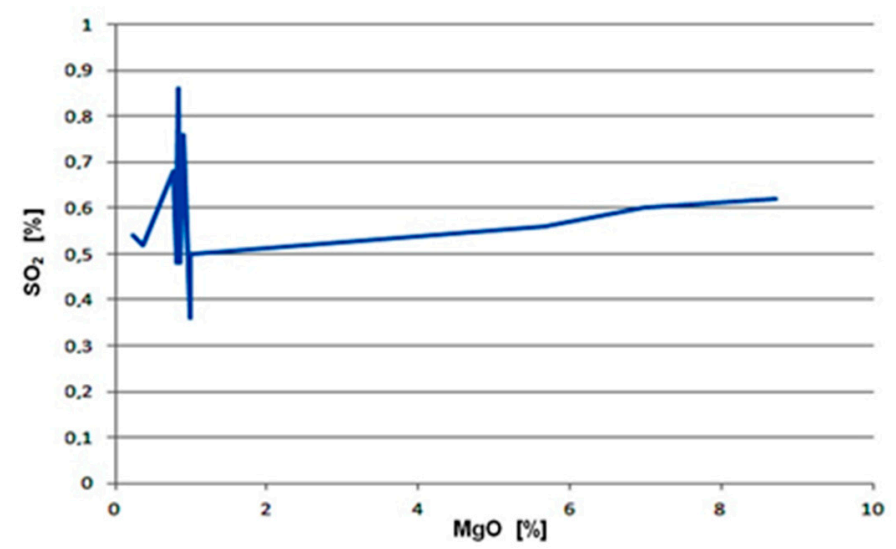

Figure 15. Relation between the amount of sulfur $\mathrm{SO}_{2}(\%)$ of the post-reaction product and the $\mathrm{MgO}(\%)$ content of carbonate sorbent [21]. 


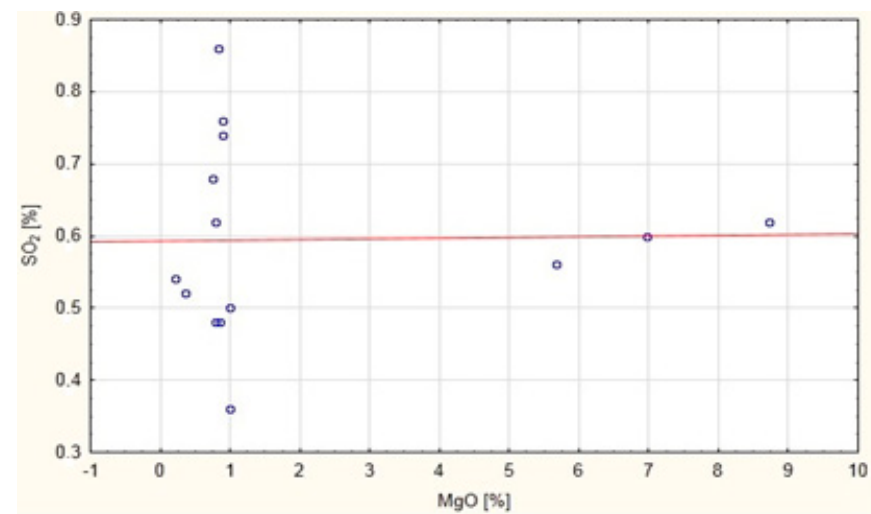

Figure 16. The amount of absorbed $\mathrm{SO}_{2}(\%)$ of the post-reaction product by carbonate sorbent samples with varied content of the $\mathrm{MgO}(\%)$ [21]. Red line- the trend line of the probable increase.

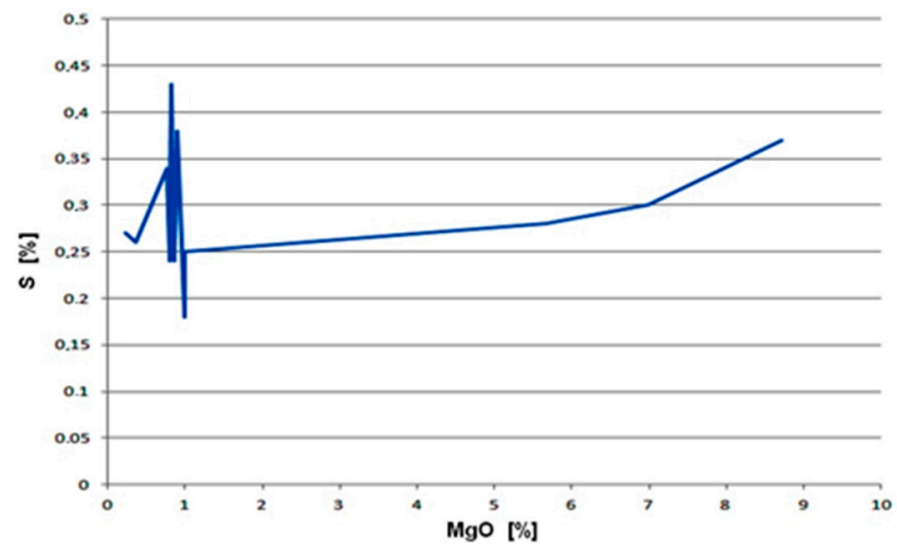

Figure 17. Relation between the amount of sulfur S (\%) of the post-reaction product and the $\mathrm{MgO}(\%)$ content of carbonate sorbent [21].

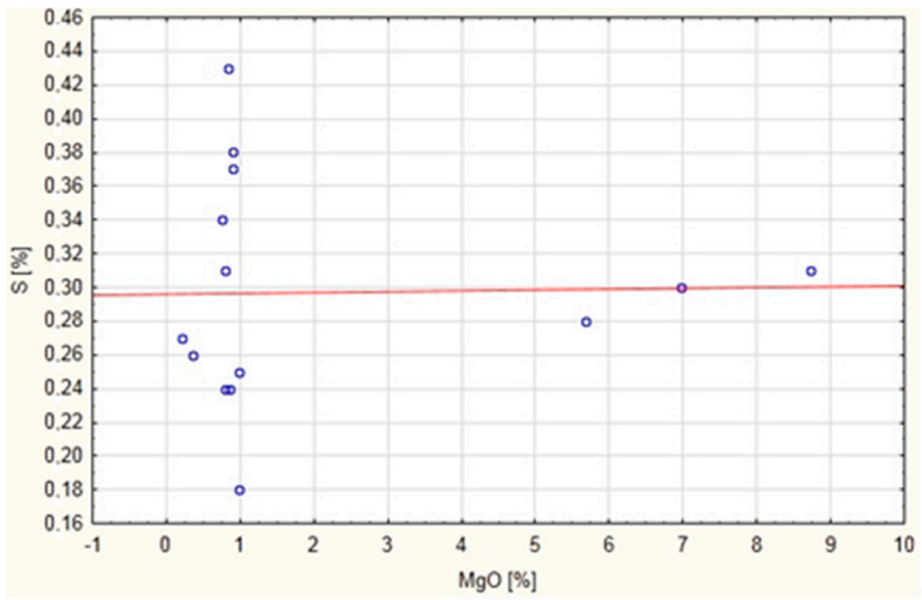

Figure 18. The amount of absorbed sulfur S (\%) of the post-reaction product by carbonate sorbent samples with varied content of $\mathrm{MgO}(\%)$ [21]. Red line- the trend line of the probable increase.

The test results showed little variation in $\mathrm{SO}_{2}$ absorption depending on the $\mathrm{MgO}$ content in the samples. In some cases, an increase in $\mathrm{SO}_{2}$ absorption was observed with increasing $\mathrm{MgO}$ in the samples. However, this is not a definite trend, with a sinuous growth character (Figures 15-18), which was observed during the research on the sorption properties of the limestones of the Karchowice Unit from the region of Tarnów Opolski [48,49]. A clear upward trend is observed only when the $\mathrm{MgO}$ content in the sorbent samples exceeds $1 \%$. 
The slight variation in the value of sulfur dioxide absorbed by the calcareous sorbent samples may also be the result of a variable $\mathrm{SO}_{2}$ stream flow through the installation (Table 3) and may also be related to the nature of the specific surface of the sorbent sample subjected to the sorption process $[21,48,49]$. Similar dependencies were shown by the calculated sulfur contents determined in the post-reaction product (Figures 17 and 18). This confirms the thesis that it is possible to observe the influence of the $\mathrm{MgO}$ content on the amount of absorbed $\mathrm{SO}_{2}$ and the efficiency of the flue gas desulfurization using a sorbent in which the amount of $\mathrm{MgO}$ will exceed the value of $1 \%$ [21,48,49].

The obtained results show that the influence of $\mathrm{MgO}$ content on the amount of absorbed $\mathrm{SO}_{2}$ is observed if the amount of $\mathrm{MgO}$ will exceed the value of $1 \%$. In this case, also an increase in and the efficiency of the flue gas desulfurization can be seen. However, no linear relationship was observed between the $\mathrm{MgO}$ content and the absorbed $\mathrm{SO}_{2}$. It could be connected with a various amount of carbonate phases differentiated in the Mg content. The decarbonization of each of these phases probably starts at a different temperature. Moreover, the presented results are data obtained during the laboratory study. The next stage of the research will be connected with conducting the tests at a power plant. The results of these studies will provide more information on the effect of $\mathrm{MgO}$ content on the flue gas desulphurization process.

3.2.2. Application of Limestones Built of Carbonates with Increased Mg Content as a Sorbent in Flue Gas Desulfurization

The obtained data are very important due to the possibility of using limestone with magnesium as a sorbent in flue gas desulfurization in power stations. Usually limestone built mainly of "pure", low-Mg calcite with a MgO content below $2 \%$ is used. However, it can be said that limestones containing carbonate minerals with increased $\mathrm{Mg}$ contents could be a better sorbent than the limestone built only of "pure" low magnesium calcite without the substitution of magnesium. A limestone containing carbonate phases rich in magnesium could be applied as a sorbent in a dry method of flue gas desulfurization. Then, the combustion of coal takes place in the Fluidized Bed Reactor $[21,39,40,48,49]$. The efficiency of the method using a Fluidized Bed Reactor is 95\%. Using this method, flue gas desulfurization is running in a bed that contains a fluidized stream of air including very small grains of fly ash, particles of sorbent and fuel.

In the case of using a limestone built only of low-Mg calcite as a sorbent, two chemical reactions run during flue gas dry desulfurization $[39,40]$. The reactions are presented below.

Disintegration of $\mathrm{CaCO}_{3}$. (calcination) $\left(890^{\circ} \mathrm{C}\right)$

$$
\mathrm{CaCO}_{3}=\mathrm{CaO}+\mathrm{CO}_{2}
$$

Binding of $\mathrm{SO}_{2}$ by $\mathrm{CaO}$. $\mathrm{CaSO}_{4}$ is formed

$$
\mathrm{CaO}+\mathrm{SO}_{2}+0.5 \mathrm{O}_{2}=\mathrm{CaSO}_{4}
$$

Three chemical reactions run during the desulfurization process, if dolomite is used as a sorbent $[39,40]$. The reactions are presented below.

Dolomite disintegration

$$
\mathrm{CaCO}_{3} \cdot \mathrm{MgCO}_{3}=\mathrm{CaCO}_{3}+\mathrm{MgCO}_{3}
$$

Carbonates calcination

$$
\begin{aligned}
\mathrm{MgCO}_{3} & =\mathrm{MgO}+\mathrm{CO}_{2}\left(750^{\circ} \mathrm{C}\right) \\
\mathrm{CaCO}_{3} & =\mathrm{CaO}+\mathrm{CO}_{2}\left(890^{\circ} \mathrm{C}\right)
\end{aligned}
$$


Reaction of binding $\mathrm{SO}_{2}$ by decarbonates

$$
\begin{gathered}
\mathrm{CaO}+\mathrm{SO}_{2}+0.5 \mathrm{O}_{2}=\mathrm{CaSO}_{4} \\
2 \mathrm{MgO}+\mathrm{SO}_{2}+0.5 \mathrm{O}_{2}=\mathrm{MgSO}_{4}+\mathrm{MgO}
\end{gathered}
$$

If dolomite is used as a sorbent for flue gas desulfurization in power stations, the efficiency of the process is much better. It is connected with the decarbonization of dolomite in lower temperatures than the decarbonization temperature of calcite. Then, the reaction of decarbonates with flue gases starts earlier and the time of the reaction is longer. However, the dolomite is characterized by worse physical properties (for example, hardness). Moreover, a periclase is present in the post-reaction product. That is the reason that dolomite is very seldom used as a sorbent for flue gas desulfurization in power stations in Poland. Therefore, instead of dolomite, it will be better to use a limestone that contains, apart from low magnesium calcite, carbonates with increased contents of $\mathrm{Mg}$ - high-Mg calcite, dolomite and huntite [21,26]. The decarbonization of minerals rich in $\mathrm{Mg}$ in lower temperatures is related to the difference in the ion size of calcium and magnesium. It is also connected with the strength of the ionic bonds. The substitution of Mg ions in crystal structures of carbonate minerals causes a weakness in the ionic bond strength. Due to this, the decomposition of the "pure", low-Mg calcite cell is more difficult and goes slower than the decomposition of the high-Mg calcite cell, the cell of dolomite and also the cell of huntite. Therefore, the decarbonization of carbonate phases with increased Mg contents runs at lower temperatures than the decarbonization of "pure", low magnesium calcite $[21,26]$. Lower temperatures of the decarbonization process of carbonate minerals with increased $\mathrm{Mg}$ contents cause earlier oxide secretion from carbonates and also the earlier binding of sulfur oxides by decarbonates. The effect of the binding of sulfur oxides by decarbonates is REA (abbreviation from Rauchgas-Entschwefelungs-Anlage) gypsum formation. Thus, applying the sorbent that contains carbonates rich in magnesium causes the flue gas desulfurization to be more effective. Then, a limestone including high magnesium calcite, dolomite and also huntite would be a better sorbent for flue gas desulfurization than a limestone built only of "pure", low magnesium calcite.

The product of dry desulfurization includes lots of different components [26,39,40,42]. Generally, the following three types of post-reaction products can be distinguished: fly ash, slag and chemical compounds. The compositions of these products are presented below $[39,40]$.

Fly Ash-It is fine grained material built of grains smaller than $0.1 \mathrm{~mm}$. It contains different types of minerals and also a glassy substance. Fly ash contains the following minerals: mullite (the contents from $10 \%$ to $20 \%$ ), quartz (the contents from $4 \%$ to $15 \%$ ), calcite (the contents from $0.8 \%$ to $3.4 \%$ ), hematite (the contents from $2 \%$ to $9.5 \%$ ), magnetite (the contents from $0.9 \%$ to $12 \%$ ), $\mathrm{CaO}$ (the contents from $0.6 \%$ to $12 \%$ ), periclase- $\mathrm{MgO}$ (the contents from $2 \%$ to $3 \%$ ) and gypsum (the contents from 1\% to $2 \%$ ). Moreover, heavy metals such as $\mathrm{As}, \mathrm{Be}, \mathrm{Cd}, \mathrm{Cr}, \mathrm{Co}, \mathrm{Zn}, \mathrm{Pb}, \mathrm{Cu}, \mathrm{Ni}, \mathrm{V}$ are present. Fly ash could also include chemical elements such as $\mathrm{Al}, \mathrm{Hg}, \mathrm{Mn}, \mathrm{Se}, \mathrm{Tl}[37,38,41,42]$.

Slag-It is coarse-grained material. Its composition is similar to the fly ash components [37,38,41,42].

Chemical compounds-They are usually the products of chemical reactions between $\mathrm{SO}_{2}$ and $\mathrm{CaO}$. They include gypsum $\left(\mathrm{CaSO}_{2} \cdot 2 \mathrm{H}_{2} \mathrm{O}\right)$; anhydrite $\left(\mathrm{CaSO}_{2}\right)$; calcium sulfate $\left(\mathrm{CaSO}_{3}\right)$; calcium oxide $(\mathrm{CaO})$; periclase $(\mathrm{MgO})$, when dolomite is used as a sorbent; calcium chloride $\left(\mathrm{CaCl}_{2}\right)$; aluminosilicates of $\mathrm{Ca}, \mathrm{K}$ and $\mathrm{Mg}$; ettringite $\left(\mathrm{Ca}_{6} \mathrm{Al}_{2}\left[(\mathrm{OH})_{4} \mathrm{SO}_{4}\right] 3 \cdot 24 \mathrm{H} 2 \mathrm{O}\right)$; magnetite $\left(\mathrm{Fe}_{2} \mathrm{O}_{3}\right)$; pyrrhotine $(\mathrm{FeS})$ and particles of sorbent $\left(\mathrm{CaCO}_{3}\right)[37,38,41,42]$.

When limestone containing only low-Mg calcite is used as a sorbent, the content of $\mathrm{MgO}$ is below $2 \%$ and then REA-gypsum is formed during flue gas desulfurization. REA-gypsum, after special adaptation, is used usually in building construction and in other industries [42]. 
However, before using, REA-gypsum must be specially adapted depending on the type of application $[21,26,37,42,48,49]$. If limestone that contains, apart from low-Mg calcite, carbonates with increased $\mathrm{Mg}$ contents (high magnesium calcite, dolomite, huntite) is applied as a sorbent in flue gas desulfurization, the post-reaction product will contain, apart from calcium phases such as gypsum and anhydrite, magnesium phases, which are also formed when dolomite is used as a sorbent. In this case, it will be necessary to examine the post-reaction product that includes magnesium sulfates and periclase to determine the possibilities of its use. Application of flue gas desulfurization is very important. It is connected with application of hard coal or brown coal as the main sources of energy in Polish power stations but also in power stations in other countries. Polish coals but also coals of other countries contain an increased content of sulfur. Therefore, in power plants, flue gas desulfurization must be applied to reduce the emission of sulfur oxides released into the atmosphere during coal combustion $[21,26,43,44]$. It is a way of protecting the air from the pollution and contamination. The sulfur oxides are usually secreted during energy production when coal is applied as the energy source. However, the application of a sorbent including carbonate phases rich in magnesium such as high magnesium calcite, dolomite and huntite could cause the flue gas desulfurization to be much more energy-consuming than in case of a limestone built mainly of low magnesium calcite being used. Moreover, the use of limestone including carbonates rich in $\mathrm{Mg}$ as a sorbent may cause an increase in the costs of conducting desulfurization $[37,40,48,49]$. It could be connected with severe corrosion of equipment in the system and the presence of the post-reaction products that are soluble in water, such as magnesium sulfate. Therefore, it is very important to very carefully analyze and calculate the amount of carbonate phases rich in magnesium that are present in the sorbent applied in flue gas desulfurization, the type of sorbent, and moreover, the type of desulfurization method used in the power station, and estimate the probable post-reaction product that could be formed during the desulfurization process. All these factors should be analyzed before making a decision related to the selection of the type of sorbent, especially the material including carbonates with an increased magnesium content for flue gas desulfurization.

\section{Discussion}

The main reason for this research was to indicate the possibility of applying limestone including carbonate phases with increased contents of $\mathrm{Mg}$ in the process of flue gas desulfurization.

Magnesium is one of the components of high-Mg calcite, protodolomite, ordered dolomite and huntite crystals. These carbonate minerals occur in the Triassic limestones of Opole Silesia [1-32,49-51].

This was demonstrated by the results of the conducted analyses, mainly X-ray diffraction, Fourier Transform Infrared Spectroscopy (FTIR) and X-ray microanalysis (microprobe measurements). On the basis of the X-ray diffraction and the Fourier Spectrometry (FTIR) results, low magnesium calcite, high magnesium calcite, dolomite and also huntite were determined. The results of the $\mathrm{X}$-ray microanalysis (microprobe measurements) confirmed the results of the X-ray diffraction and the Fourier Spectrometry (FTIR). The obtained data show that four carbonates with various contents of $\mathrm{Mg}$ built the investigated limestones. Moreover, the identified dolomite can be treated as an ordered dolomite, because the value of its $\mathrm{Mg}$ content is close to the stoichiometric value for dolomite $(\mathrm{Mg}=13.18 \%$, $\mathrm{MgO}=21.86 \%$ ).

Moreover, a study of sorption properties was conducted. They have been compared with the results of previous studies [18-28,48,49].

The results of the earlier conducted research have shown that an increased content of magnesium in the sorbent has a positive effect on the technological process of flue gas desulfurization using the dry method, especially in the case of desulfurization with the use of the Fluidized Bed Reactor $[39,45,48,49]$. The presence of magnesium in dolomite has a positive effect on the sorption of sulfur oxides during flue gas desulfurization, due to 
the fact that dolomite has a calcination temperature lower than calcite by $200 \mathrm{~K}$, and the decomposition process runs in stages [39,52-54]. Therefore, magnesium calcite, dolomite and huntite will undergo calcination at lower temperatures than "pure" (low magnesium) calcite.

The $\mathrm{MgCO}_{3}$ of dolomite decomposition runs in the temperature range of $600-750{ }^{\circ} \mathrm{C}$ (873-1023 K), while the still undecomposed calcium carbonate contains admixtures of magnesium carbonate $\left(\mathrm{MgCO}_{3} \cdot \mathrm{nCaCO}_{3}\right)$ in the form of a solid solution [54].

This reaction is illustrated by the following equation [26]:

$$
\mathrm{CaMg}\left(\mathrm{CO}_{3}\right)_{2}=\mathrm{CaMg}(1-\mathrm{x})\left(\mathrm{CO}_{3}\right)_{(2-\mathrm{x})}+\mathrm{xMgO}+\mathrm{xCO}_{2} \text { (periclase) }
$$

As the temperature increases, the remaining calcium carbonate particles decompose with the simultaneous secretion of $\mathrm{CaO}$ and $\mathrm{MgO}$. The process of the decomposition of a calcium carbonate containing the substitutions of magnesium ions, will, however, start at temperatures lower than in the case of the decomposition of "pure" calcium carbonate ( $\mathrm{min}$. before $890^{\circ} \mathrm{C}-1163 \mathrm{~K}$ ). This is due to the fact that the structure of a solid solution containing magnesium ions, with a smaller ion radius than calcium ions, is unstable $[40,41,48-51,55,56]$. When the temperature in the combustion chamber increases, the specific surface of the sorbent grains is reduced due to the narrowing of the lattice parameters and the reduction in porosity. This results in the sintering of the sorbent grains [54].

The decrease in the surface area of $\mathrm{CaO}$, which absorbs sulfur oxides, restricts the kinetics of the reaction. As a result of the ongoing process, calcium sulphate or sulphite is formed, which "closes" the decarbonate conglomerate, preventing a further sorption reaction. The presence of magnesium in the sorbent, bound in carbonates, causes the decomposition of these carbonate crystals at lower temperatures than "pure" calcite. Therefore, the reaction time of the decarbonate with sulfur oxides is longer $[40,41,48,49,56]$.

When analyzing the previous results of the research, it can be assumed that the calcination of the sorbent containing high magnesium calcite, dolomite and huntite will be probably analogous to that of the typical dolomite sorbent. This theory is based on the crystallochemical similarity of magnesium calcite and dolomite crystals [48,54]. Probably, at lower temperatures than is typical for "pure" calcite decomposition, due to the high contents of magnesium, apart from dolomite, huntite will also decompose. Therefore, limestones containing magnesium bound in crystal structures of high-Mg calcite, dolomite and huntite have more favorable properties, from the point of view of the flue gas desulfurization process, than limestones built only of "pure", low-Mg calcite.

The microprobe measurements conducted in microareas of limestone samples showed that a significant part of magnesium occurs as a substitution in high magnesium calcite crystals; some forms dolomite (consistent with the stoichiometric composition), and a small amount also occurs in huntite crystals.

The magnesium present in the rocks is distributed in various proportions in the high magnesium calcite, protodolomite, ordered dolomite and huntite crystals [48,49]. This may affect the nature of the specific surface of the rock samples tested for sorption properties. The results of sorption tests showed that in some cases an increase in $\mathrm{SO}_{2}$ absorption was observed with an increase in the $\mathrm{MgO}$ in the samples. However, this is not such a clear linear trend as was observed during the research on the sorption properties of the limestones of the Karchowice Unit from the Tarnów Opolski area [48,49]. A clear linear trend was observed when the amount of $\mathrm{MgO}$ in the sorbent samples exceeded the value of $1 \%$. It is probably connected with a various amount of carbonate phases differentiated in magnesium content. The decarbonization of each of these phases presumably starts at a different temperature. Moreover, the presented results are data obtained during the laboratory study.

The results of the research indicate that it is necessary to conduct additional tests, at least on a semi-technological scale, which would allow the author to determine, more precisely, the effect of $\mathrm{MgO}$ content not only on the amount of $\mathrm{SO}_{2}$ absorbed, but also on the 
effectiveness of the desulfurization process. Increasing the efficiency of the desulfurization process will be connected with the decomposition of magnesium-containing carbonates at lower temperatures than the "pure" calcite $[40,41,48,49,56]$. Due to this, the process of the sulfur oxide binding would begin earlier. Therefore, it would be better to use the limestones containing an increased magnesium content, because of the presence of carbonate phases with magnesium, than the carbonate sorbent with a permissible content of $\mathrm{MgO}-2 \%$, especially in the flue gas desulfurization process in power plants using the "dry" desulfurization technology, mainly Fluidized Bed Reactor installations [40,41,48,49].

However, the application of a sorbent including carbonate minerals with an increased $\mathrm{Mg}$ content could cause the flue gas desulfurization to be much more energy consuming. Moreover, the use of limestone, including carbonates rich in $\mathrm{Mg}$, as a sorbent may cause an increase in the costs of conducting desulfurization because of the possible severe corrosion of the equipment used in the applied system. However, the use of an appropriate technology may limit the negative impact of the application of a sorbent rich in $\mathrm{Mg}$ on the flue gas desulphurization system. However, limestone containing carbonate minerals with an increased $\mathrm{Mg}$ content would be a better sorbent than typical dolomite because of the worse physical properties of dolomite, mainly its higher hardness. Besides the higher content of periclase and magnesium sulfates that occur in the post-reaction product, this material is more difficult to use than the material containing principally calcium phases with a low content of magnesium phases, in particular periclase-MgO. Periclase is an inert phase that does not react with other substances. Therefore, its adaptation for application is reduced. However, the periclase is a mineral that is not dangerous for the environment.

\section{Conclusions}

Based on the research results obtained, the following conclusions were formed, which can be summarized as follows:

1. The research results confirmed the presence of four carbonate minerals in the Triassic limestones of the Opole Silesia in Poland. Some of them present increased Mg contents. They are low magnesium calcite, (Low-Mg calcite), high magnesium calcite (High-Mg calcite), dolomite, mainly ordered dolomite and huntite. The minerals phases are characterized by various magnesium contents.

2. The influence of the magnesium content on the sorption properties of limestones was determined based on the data obtained as a result of the sorption properties research.

3. The results of the research showed that an increased content of magnesium in the sorbent has a positive effect on the technological process of flue gas desulfurization using the dry method, especially in the case of desulfurization with the application of Fluidized Bed Reactors.

4. The positive influence of magnesium presence in sorbent on the desulfurization process is connected with the decarbonization of carbonate phases with magnesium that takes place at temperatures that are lower than the decarbonization temperature of low magnesium calcite.

5. In the process of decarbonization, it is easier to use a calcium carbonate containing the substitutions of magnesium ions. It starts and runs at lower temperatures because the structure of a solid solution containing magnesium ions, with a smaller ion radius than calcium ions, is unstable and decomposition of these phases runs easier and faster.

6. The results of this research indicate that the decomposition of dolomite runs earlier and faster than the decomposition of low-Mg calcite. Therefore, because of magnesium's presence, the decomposition of high-Mg calcite and huntite will run similarly to the decomposition of dolomite, i.e., earlier and faster than the decomposition of low-Mg calcite.

7. Due to the faster decarbonization of carbonates with magnesium, the desulfurization process will start earlier and at lower temperatures. It will cause an increase in the efficiency of this process. 
8. However, the application of a sorbent including carbonate minerals with an increased $\mathrm{Mg}$ content could cause the flue gas desulfurization to be much more energy consuming. Moreover, the use of this type of sorbent may cause an increase in the costs of conducting desulfurization because of the possible severe corrosion of the equipment used in the applied system. However, the use of an appropriate technology may limit the negative impact of using limestone containing carbonates rich in magnesium as a sorbent in the system of flue gas desulfurization.

9. Moreover, the presence of periclase in the post-reaction product may restrict the use of this product in some branches of the industry. However, the periclase is an inert material that does not react with other substances, and it is not dangerous for the environment. Therefore, the proper preparation of the post-reaction product including periclase will allow to use this product.

10. To sum up, on the basis of the research results and their analysis, it should be stated that limestones containing carbonate minerals with an increased $\mathrm{Mg}$ content will be a better sorbent than "pure" limestone, which is built mainly of low magnesium calcite.

Funding: My research did not receive any specific grant from funding agencies in the public, commercial, or not-for-profit sectors.

Data Availability Statement: The data presented in this manuscript can be found in the cited articles and in the author's database.

Conflicts of Interest: The author declares no conflict of interest.

\section{References}

1. Althoff, P.L. Structural refinements of dolomite and a magnesian calcite and implications for dolomite formation in the marine environment. Am. Mineral. 1977, 62, 772-783. Available online: https://rruff.info/doclib/am/vol62/AM62_772.pdf (accessed on 26 July 2021).

2. Atay, H.Y.; Çelik, E. Use of Turkish huntite/hydromagnesite mineral in plastic materials as a flame retardant. Polym. Compos. 2010, 31, 1691-1700. [CrossRef]

3. Bertram, M.A.; Mackenzie, F.T.; Bishop, F.C.; Bischoff, W.D. Influence of temperature on the stability of magnesian calcite. Am. Mineral. 1991, 76, 1889-1896.

4. Boggs, S., Jr. Petrology of Sedimentary Rocks, 2nd ed.; Cambridge University Press: Cambridge, UK, 2010; pp. 313-457. Available online: http:/ / www.minsocam.org/ammin/AM76/AM76_1889.pdf (accessed on 26 July 2021).

5. Böttcher, M.E.; Gehlken, P.L.; Fernández-González, Á.; Prieto, M. Characterization of synthetic $\mathrm{BaCO}_{3}-\mathrm{SrCO}_{3}$ (witheritestrontianite) solid-solutions by Fourier transform infrared spectroscopy. Eur. J. Mineral. 1997, 9, 519-528. [CrossRef]

6. Böttcher, M.E.; Gehlken, P.L.; Steele, F.D. Characterization of inorganic and biogenic magnesian calcites by Fourier Transform infrared spectroscopy. Solid State Ion. 1997, 101-103, 1379-1385. [CrossRef]

7. Böttcher, M.E.; Dietzel, M. Metal-ion partitioning during low-temperature precipitation and dissolution of anhydrous carbonates and sulphates. In Ion Partitioning in Ambient-Temperature Aqueous Systems; GeoScienceWorld: McLean, VA, USA, 2010; Volume 10, pp. 139-187. [CrossRef]

8. Cole, W.F.; Lancucki, C.J. Huntite from Deer Park, Victoria, Australia. Am. Mineral. 1975, 60, 1130-1131.

9. Deelman, J.C. Low-Temperature Formation of Dolomite and Magnesite. 2011. Available online: http://www.jcdeelman.demon. nl/dolomite/files/13_Chapter6.pdf (accessed on 26 July 2021).

10. Dollase, W.A.; Reeder, R.J. Crystal structure refinement of huntite, $\mathrm{CaMg}_{3}\left[\mathrm{CO}_{3}\right]_{4}$, with X-ray powder data. Am. Mineral. 1986, 71, 163-166. Available online: https:/ / citeseerx.ist.psu.edu/viewdoc/download?doi=10.1.1.561.927\&rep=rep1\&type=pdf (accessed on 26 July 2021).

11. Faust, G.T. Huntite, $\mathrm{Mg}_{3} \mathrm{Ca}\left(\mathrm{CO}_{3}\right)_{4}$, a new mineral. Am. Mineral. 1953, 38, 4-23. Available online: https://rruff-2.geo.arizona. edu/uploads / AM38_4.pdf (accessed on 26 July 2021).

12. Graf, D.L.; Goldsmith, J.R. Some hydrothermal syntheses of dolomite and protodolomite. Benchmark Pap. Geol. 1982, 65, 70-84. Available online: https:/ / www.jstor.org/stable/30060650 (accessed on 26 July 2021). [CrossRef]

13. Kralj, D.; Kontrec, J.; Brecěvć, L.; Falini, G.; Nöthig-Laslo, V. Effect of inorganic anions on the morphology and structure of magnesium calcite- chemistry. Chem. Eur. J. 2004, 10, 1647-1656. [CrossRef]

14. Morse, J.W.; Andersson, A.J.; Mackenzie, F.T. Initial responses of carbonate-rich shelf sediments to rising atmospheric $\mathrm{pCO}_{2}$ and "ocean acidification": Role of high Mg-calcites. Geochim. Cosmochim. Acta 2006, 70, 5814-5830. [CrossRef]

15. Nash, M.C.; Troitzsch, U.; Opdyke, B.N.; Trafford, J.M.; Russell, B.D.; Kline, D.I. First discovery of dolomite and magnesite in living coralline algae and its geobiological implications. Biogeosciences 2011, 8, 3331-33340. [CrossRef] 
16. Nürnberg, D.; Bijma, J.; Hemleben, C. Assessing the reability of magnesium in foraminiferal calcite as a proxy for water mass temperatures. Geochim. Cosmochim. Acta 1996, 60, 803-814. [CrossRef]

17. Paquette, J.; Reeder, R.J. Single-crystal X-ray structure refinements of two biogenic magnesian calcite crystals. Am. Mineral. 1990, 75, 1151-1158.

18. Stanienda, K. Identification of the carbonate phases in the Karchowice and Diplopora Beds (Muschelkalk Sediments) from the Lower Silesia. Sci. J. Sil. Univ. Technol. 2005, 269, 149-157.

19. Stanienda, K. Carbonates in the Triassic rocks from the area of Tarnów Opolski. Miner. Resour. Manag. 2006, 22, $243-251$.

20. Stanienda, K. Effects of Dolomitization Processes in the Triassic Limestone of Tarnów Opolski Deposit; Silesian University of Technology Press: Gliwice, Poland, 2011; ISBN 978-83-7335-872-0.

21. Stanienda, K. Diagenesis of the Triassic Limestone from the Opole Silesia in the Aspect of Magnesian Calcite Presence; Silesian University of Technology Press: Gliwice, Poland, 2013; ISBN 978-83-7880-071-2.

22. Stanienda, K. Possibility of huntite presence in the Triassic limestones of Opole Silesia. Miner. Resour. Manag. 2013, 29, 79-98. [CrossRef]

23. Stanienda, K. Mineral phases in carbonate rocks of the Gogolin Beds from the area of Opole Silesia. Miner. Resour. Manag. 2014, 30, 17-42. [CrossRef]

24. Stanienda, K. Carbonate phases rich in magnesium in the Triassic limestones of the East part of Germanic Basin. Carbonates Evaporites 2016, 31, 387-405. [CrossRef]

25. Stanienda, K. Mineral phases in carbonate rocks of the Górażdże Beds from the area of Opole Silesia. Miner. Resour. Manag. 2016, 32, 67-92. [CrossRef]

26. Stanienda-Pilecki, K. Carbonate minerals with magnesium in Triassic Terebratula limestone in the term of limestone with magnesium application as a sorbent in desulfurization of flue gases. Arch. Min. Sci. 2017, 62, 459-482. [CrossRef]

27. Stanienda-Pilecki, K. Magnesium calcite in Muschelkalk limestones of the Polish part of the Germanic Basin. Carbonates Evaporites 2018, 33, 801-821. [CrossRef]

28. Stanienda-Pilecki, K. The importance of Fourier-Transform Infrared Spectroscopy in the identification of carbonate phases differentiated in magnesium content. Spectroscopy 2019, 34, 32-42. Available online: https://www.spectroscopyonline.com/ view / spec0619-pilecki (accessed on 26 July 2021).

29. Titiloye, J.O.; De Leeuw, N.H.; Parker, S.C. Atomistic simulation of the differences between calcite and dolomite surfaces. Geochim. Cosmochim. Acta 1998, 62, 2637-2641. [CrossRef]

30. Tsipursky, S.J.; Buseck, P.R. Structure of magnesian calcite from sea urchins. Am. Mineral. 1993, 78, 775-781. Available online: http:/ / www.minsocam.org/ammin/am78/am78_775.pdf (accessed on 26 July 2021).

31. Yavuz, F.; Kirikoğlu, M.S.; Özden, G. The occurrence and geochem istry of huntite from Neogene lacustrine sediments of the Yalvaç-Yarıkkaya Basin, Isparta, Turkey. Neues Jahrb. Fur Mineral. Abh. 2006, 182/2, 201-212. [CrossRef]

32. Zahng, Y.; Dave, R.A. Influence of $\mathrm{Mg}^{2+}$ on the kinetics of calcite crystal morphology. Chem. Geol. 2000, 163, 129-138. [CrossRef]

33. Niedźwiedzki, R. Lithostratigraphy of the Górażdże and the Dziewkowice formations in Opole Silesia. Geol. Mineral. Stud. U. Wr. LXXI 2000, 71, 1-72.

34. Szulc, J. International workshop- field seminar the muschelkalk. In Sedimentary Environments, Facies and Diagenesis; Excursion Guidebook and Abstracts; Institute of Geological Science Publishing House of Jagiellonian University: Cracow, Poland, 1990; pp. 1-32.

35. Szulc, J. Middle Triassic evolution of the Northern Peri-Tethys area is influenced by early opening of the Tethys Ocean. Ann. Soc. Geol. Pol. 2000, 70, 1-48. Available online: https://geojournals.pgi.gov.pl/asgp/article/view/12348/10822 (accessed on 26 July 2021).

36. Gaines, A.M. Protodolomite redefined. J. Sediment. Res. 1977, 47, 543-546.

37. Brylicki, W.; Lysek, N. Properties and the use of generated waste in the process of gas desulphurization in a fluidized bed (Własności a wykorzystanie odpadów powstajacych w procesie odsiarczania gazów na złożu fluidalnym). Cement. Lime. Concr. (Cem. Wapno Beton) 1996, 3, 97-103.

38. Ikavalko, E.; Laitinen, T.; Parkka, M.; Yliruokanen, I. Intercomparizon of trace-element determination in samples from a Coal Fired Power-Plant. Int. J. Environ. Anal. Chem. 1995, 61, 207-224. [CrossRef]

39. Kanafek, J.; Fojcik, E. The use of fly ash in mining-Technical aspects (Wykorzystanie popiołów lotnych w górnictwie- aspekty techniczne). Environ. Prot. Law Policy (Ochr. Środowiska Prawo Polityka) 1998, 1, 23-34.

40. Lysek, N. Sorbents for the Desulphurization of Gases. Production and Application (Sorbenty do Odsiarczania Gazów. Produkcja $i$ Zastosowanie); Publishing House OREKOP: Krakow, Poland, 1997; ISBN 83-908066-0-6.

41. Nadziakiewicz, J.; Janusz, M. Mitigation of sulphur dioxide emission in power plant boilers. Fuel Energy Manag. (Gospod. Paliwami Energia) 1999, 12, 12-15.

42. Szlugaj, J.; Naworyta, W. Analysis of the changes in the Polish gypsum resources in the context of flue gas desulfurization in conventional power plants. Miner. Resour. Manag. 2015, 31, 93-108. [CrossRef]

43. Szlugaj, J.; Galos, K. Limestone sorbents market for flue gas desulphurisation in coal-fired power plants in the context of the transformation of the power industry-A case of Poland. Energies 2021, 14, 4275. [CrossRef]

44. Lewicka, E.; Szlugaj, J.; Burkowicz, A.; Galos, K. Sources and markets of limestone flour in Poland. Resources 2020, 9, 118. [CrossRef] 
45. Sanders, J.F.; Keener, T.C.; Wang, J. Heated fly ash, hydrate lime slurries for $\mathrm{SO}_{2}$ removal in spray drayer absorbers. Ind. Eng. Chem. Res. 1995, 34, 302-307. [CrossRef]

46. Lim, J.; Cho, H.; Kim, J. Optimization of wet flue gas desulfurization system using recycled waste oyster shell as high-grade limestone substitutes. J. Clean. Prod. 2021, 37, 128492. [CrossRef]

47. Lim, J.; Choi, Y.; Kim, G.; Kim, J. Modeling of the wet flue gas desulfurization system to utilize low-grade limestone. Korean J. Chem. Eng. 2020, 37, 2085-2093. [CrossRef]

48. Pozzi, M.; Stanienda, K. Effect of magnesium content in Triassic limestones from the 'Tarnów Opolski' deposit on their sorption properties in the flue gas desulphurization process. Sci. J. Sil. Univ. Technol. 2000, 246, 427-437.

49. Stanienda, K. The Impact of the Dolomitization of Triassic Limestones in the 'Tarnów Opolski' Deposit on the Possibility of Their Use in the Flue Gas Desulphurization Process. Ph.D. Thesis, Silesian University of Technology, Gliwice, Poland, 2000.

50. Ahn, D.J.; Berman, A.; Charych, D. Probing the dynamics of template-directed calcite crystallization with in situ FTIR. J. Phys. Chem. 1996, 100, 12455-12461. [CrossRef]

51. Pokrovsky, O.S.; Mielczarski, J.A.; Barrea, O.; Schott, J. Surface spaciation models of calcite and dolomite aqueous solution interfaces and their spectroscopic evaluation. Langmuir 2000, 16, 2677-2688. [CrossRef]

52. Ramseyer, K.; Miano, T.M.; D'Orazio, V.; Wildberger, A.; Wagner, T.; Geister, J. Nature and origin of organic matter in carbonates from speleothems, marine cements and coral skeletons. Org. Geochem. 1997, 26, 361-378. [CrossRef]

53. Ji, J.; Ge, Y.; Balsam, W.; Damuth, J.E.; Chen, J. Rapid identification of dolomite using a Fourier Transform Infrared Spectrophotometer (FTIR): A fast method for identifying Heinrich events in IODP Site U1308. Mar. Geol. 2009, 258, 60-68. [CrossRef]

54. Nadachowski, F. Outline of Refractory Technology (Zarys Technologii Materiałów Ogniotrwatych); Silesian Publishig House: Wrocław, Poland, 1972.

55. Deer, W.A.; Howie, R.A.; Zusman, J. Rock-Forming Minerals; Geological Society of Glasgow: Glasgow, UK, 1966.

56. Borkowska, M.; Smulikowski, K. Rock-Forming Minerals (Mineraty Skałotwórcze); Geological Publishers: Warsaw, Poland, 1973. 